\title{
RESEARCH PAPER ON EXPLORING TALENT MANAGEMENT PRACTICES: ANTECEDENTS AND CONSEQUENCES
}

\author{
Meenakshi Sharma \\ Research Scholar, Mody University of Science and Technology, Laxmangarh, \\ Rajasthan, India \\ Dr. B.S. Rathore \\ Ph.D. Supervisor, Professor, Mody University of Science and Technology, Laxmangarh, \\ Rajasthan, India
}

\begin{abstract}
Talent management (TM) has received lots of attention of academicians, practitioners, researchers, scholars, and competitive firms in recent years, but there are many gaps left for further theoretical and empirical development. One of gap is lack of clarity of definition of TM, and the ongoing debate about whether it is merely repackaging of already existing human resource management (HRM) practices or a new concept. In this context, this paper concludes that TM practices are distinct from the traditional HRM practices. The researcher has consolidated the existing literature on TM for designing an integrated model of TM including its antecedents and consequences. The study calls future research to empirically test the derived propositions. The paper includes various theoretical, economic, managerial, and future research implications.
\end{abstract}

Key words: Talent management practices; strategic philosophy; business strategy; management commitment; employer branding; employee engagement.

Cite this Article: Meenakshi Sharma and B.S. Rathore, Research Paper on Exploring Talent Management Practices: Antecedents and Consequences, International Journal of Management, 11(12), 2020, pp. 1332-1363.

http://iaeme.com/Home/issue/IJM?Volume $=11 \&$ Issue $=12$

\section{INTRODUCTION}

Business organizations work hard to achieve sustainable competitive advantage, but there is still a wide gap between the desired and actual success. If this gap arises due to the performance and management of employees, then effective practices (such as strategic HR management) must be undertaken to attain the desired success. Strategic management of talented and committed people, motivate other employees to exhibit their potential capabilities for the growth of the organization as a whole (Cappelli, 2008a), which enables the organization to 
outperform the competitors (Cheese et al., 2009). TM is seen as a fuel for the engine of human capital management (HCM) (Iqbal et al., 2013). Hence, its implementation is critical and a challenging factor for success and growth of the employees as well the organization as confirmed by management practitioners, experts, academicians, internet magazines, newspapers articles, and social networking sites (Powell et al., 2012; Stahl et al., 2012; McDonnell, 2011; Guthridge et al., 2008; Michaels et al., 2001). Beside this, TM has become an imperative managerial decision for each organization at all levels (Thunnissen et al., 2013; Schuler et al., 2011; Deloitte, 2010; Guthridge et al., 2008; Paauwe, 2007; Donahue, 2001) to meet the various challenges vis-à-vis, globalization, expansion, diversification, changing demography, and inadequate development.

TM strategies such as talent identification, talent attraction, talent development, talent retention, talent engagement, talent review, talent ship, talent segmentation are being implemented by the HR executives to adjust and manage the future talent shortages or to meet the talent gap in present and upcoming phase of the organization (Schuler et al., 2011; Deloitte, 2010; Tarique and Schuler, 2010; Beechler and Woodward, 2009; Basri and Box, 2008).

Further, the increasing attention towards TM persuades us to rethink about how to supervise and implement TM practices effectively and constantly, so that it yields positive outcomes for the organizations.

Further, the conceptual framework of TM is still at developing stage. Silzer and Dowell (2010), Collings and Mellahi (2009), Lewis and Heckman (2006) have explored four approaches of TM:

- Emphasized and defined human capital as talent

- Role of TM in projecting employee needs and managing progression of these employees

- $\mathrm{TM}$ is an instrument to achieve economic outcomes by focusing on internal talent pools and their talent categorization.

- Identification of key positions that have a significant impact on a company's competitive advantage.

Additionally, majority of work on TM in academic literature tries to respond to the question: what is TM? (Thunnissen et al., 2013). Further, the lack of integration of key elements of the TM system has been identified as a major weakness of the TM system (Farndale et al., 2010) due to which organisations are unable to develop and implement effective TM programs or practices (Vaiman et al., 2012). Therefore, the scope of this exploratory research has been broadened by the considerable debate regarding factors affecting TM practices.

Further, the effectiveness of TM and its added value to organization and employees has not been evaluated at length. Much of the extant research on TM to date has been at organizational level only and on the structural aspects of TM strategies (Makela et al., 2010). This paper aims at bridging aforementioned research gap by drawing an integrated model of TM, which can be used by HR managers or practitioners for managing talented employees and for enhancing organizational reputation at two levels (financial and non-financial). The present study framework allows us to extend the TM theory in a new direction.

In this paper, the researcher has explored TM as a multiple practices phenomenon rather than as a single practice, which starts from the identification of employee followed by succession planning, development, and retention through review of literature (Table 1). Further, these practices are interrelated (see Figure 1). Next, researcher has explored the potential predictors for each TM practice and investigated the consequences of each TM practice in terms of financial and non-financial outcomes at organizational as well as employee level. 
Figure 2 provides a conceptual framework, based on the review of literature. The rest of the paper includes review of literature of talent, TM, traditional and modern views about TM, antecedents, and consequences of TM. The researcher has advanced a conceptual model, based on which research propositions have been framed. After discussing the theoretical, economic, and managerial contributions, researcher has put forth the implications for each. The paper concludes with implications for future research.

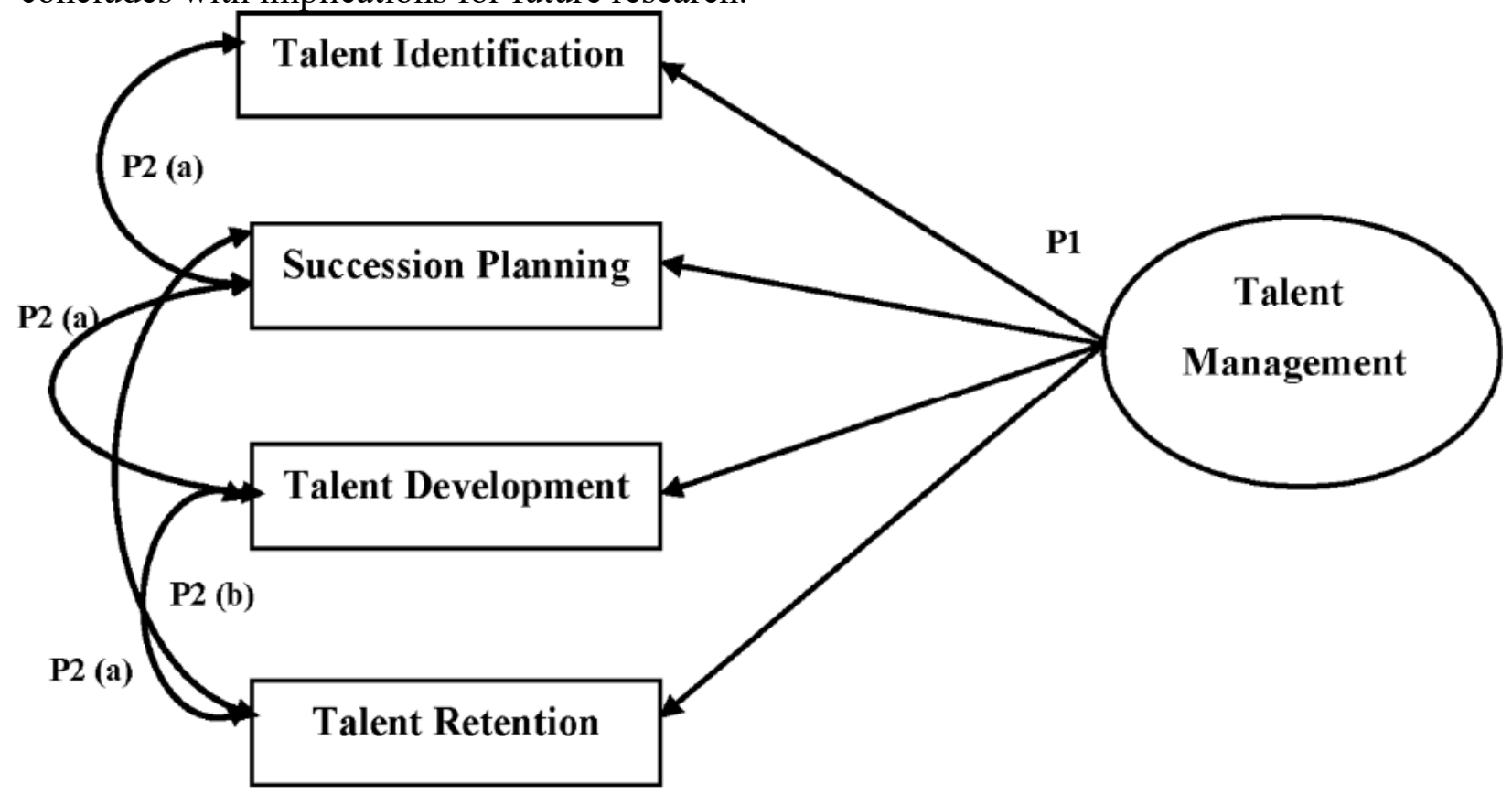

Figure 1 Reflective model of talent management

*In a reflective model, a latent variable is posited as the common cause of item or indictor behaviour. It is applied when the observed variable are chosen and measured as they are assumed to be reflective of the prior theoretical latent construct (Coltman et al.,2008).

\section{Talent Management}

$\begin{array}{lll}\text { Antecedents } & \text { Practices Consequences }\end{array}$
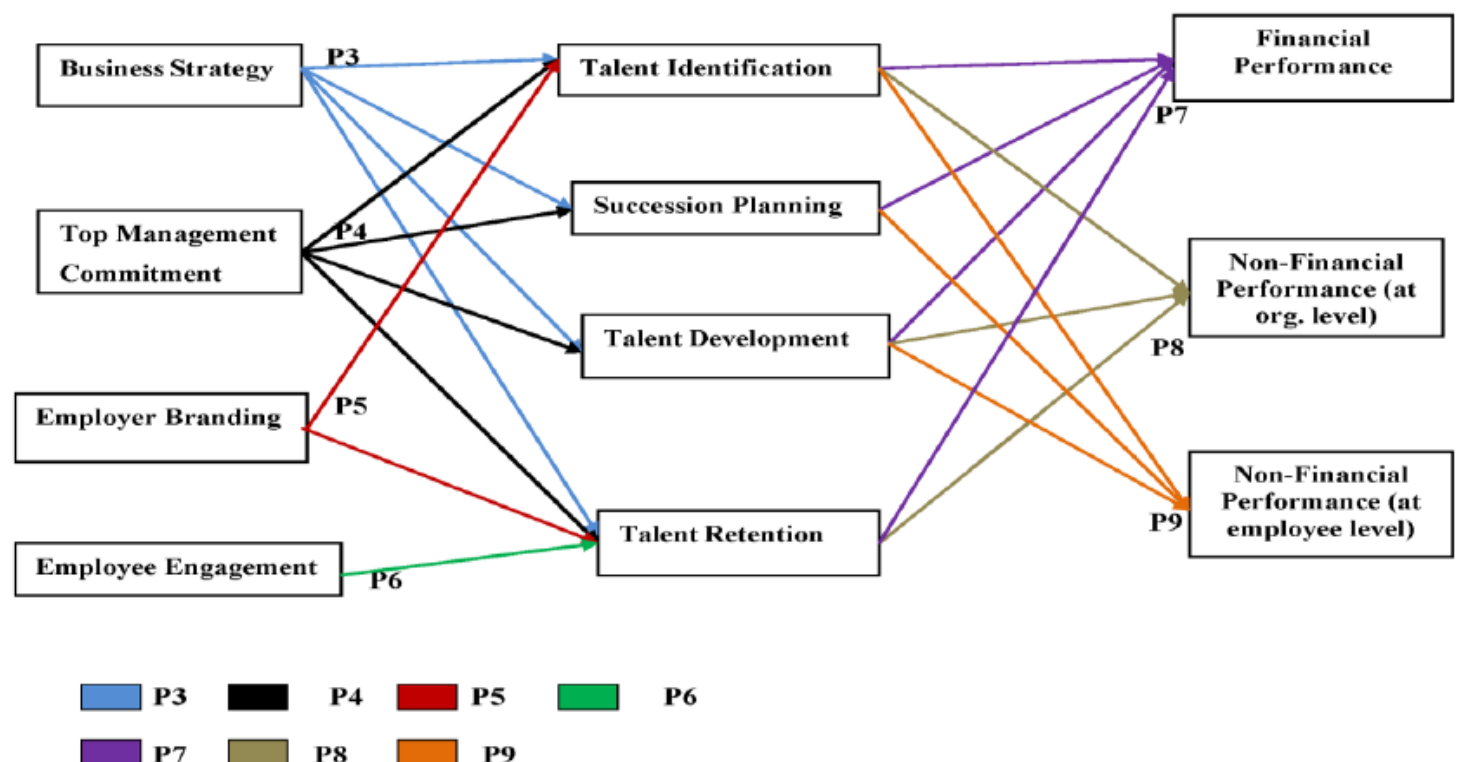

Figure 2 Antecedents and consequences of talent management practices (see online version for colours) 
Table 1 Tabular presentation of literature reviewed on talent management

\section{A. Studies related to TM Practices}

\begin{tabular}{|c|c|c|c|}
\hline Study By & Conducted At & Research Aim & Research Outcome \\
\hline 1. Groschl (2009) & $\begin{array}{l}\text { Internationally Operating } \\
\text { Hotel Groups }\end{array}$ & $\begin{array}{l}\text { An exploratory } \\
\text { research was conducted } \\
\text { to explore the corporate } \\
\text { diversity statements } \\
\text { among these hotels. }\end{array}$ & $\begin{array}{l}\text { With the help of Talent } \\
\text { Recruitment practices, he } \\
\text { tried to bring out the } \\
\text { solution. }\end{array}$ \\
\hline 2. Analoui (2007) & \multicolumn{3}{|c|}{$\begin{array}{l}\text { He identified the importance of Competency Based Recruitment Practices followed by } \\
\text { Training \& Development of the workforce. }\end{array}$} \\
\hline 3. Beal (2005) & $\begin{array}{l}\text { UPS company of New } \\
\text { York City }\end{array}$ & $\begin{array}{l}\text { An exploratory research } \\
\text { was conducted to sustain } \\
\text { the employees in the } \\
\text { yester years. }\end{array}$ & $\begin{array}{l}\text { With the help of TM } \\
\text { practices like, Job } \\
\text { Rotation, stretch work } \\
\text { assignments, cross } \\
\text { functional movements. }\end{array}$ \\
\hline 4. Hay (2002) & \multicolumn{2}{|c|}{$\begin{array}{l}\text { A primary study was conducted to identify the three } \\
\text { important factors for employee attrition emerging out of } \\
\text { improper talent management practices. Three factors } \\
\text { leading to employee attrition are lack of use of skills } \\
\text { and abilities, unhappiness with the boss, and a lack of } \\
\text { opportunity to learn new skills. }\end{array}$} & $\begin{array}{l}\text { Talent management } \\
\text { practices like employee } \\
\text { training over regular } \\
\text { intervals to develop skills, } \\
\text { offering Job rotation } \\
\text { helped for the same. }\end{array}$ \\
\hline $\begin{array}{l}\text { 5. Govaerts et. al } \\
(2010)\end{array}$ & $\begin{array}{l}\text { Professional organizations } \\
\text { on } 972 \text { employees. }\end{array}$ & $\begin{array}{l}\text { An exploratory study was } \\
\text { conducted for employee } \\
\text { retention. }\end{array}$ & $\begin{array}{l}\text { Main emphasis was levied } \\
\text { upon learning and } \\
\text { development. }\end{array}$ \\
\hline $\begin{array}{l}\text { 6. Mitra, Gupta, \& } \\
\text { Shaw (2011) }\end{array}$ & \multicolumn{3}{|c|}{$\begin{array}{l}\text { They conducted a study across } 214 \text { organizations and found that skill based pay plan } \\
\text { leads to positive workforce attitude towards the job. }\end{array}$} \\
\hline $\begin{array}{l}\text { 7. Kuvaas \& Dysvik } \\
\text { (2005) }\end{array}$ & $\begin{array}{l}\text { A cross-sectional survey } \\
\text { on } 803 \text { employees across } 3 \\
\text { orgns. located in Norway. }\end{array}$ & $\begin{array}{l}\text { To test the relationship } \\
\text { between performance } \\
\text { appraisal reactions and } \\
\text { employee outcomes. }\end{array}$ & $\begin{array}{l}\text { The findings revealed } \\
\text { talent management } \\
\text { practices in form of good } \\
\text { Performance Appraisal are } \\
\text { directly related to affective } \\
\text { commitment by employees. }\end{array}$ \\
\hline $\begin{array}{l}\text { 8. Grobler, et. al } \\
(2002)\end{array}$ & $\begin{array}{l}\text { He conducted his research } \\
\text { on } 1350 \text { employees of } \\
\text { various organizations in } \\
\text { Germany. }\end{array}$ & $\begin{array}{l}\text { Main aim was to bring } \\
\text { out major reasons for } \\
\text { employee turnover in } \\
\text { those organizations. } \\
\text { [Role of Equity Theory] }\end{array}$ & $\begin{array}{l}\text { He found the inadequate } \\
\text { compensation as the main } \\
\text { reason \& focused more on } \\
\text { the performance based pay } \\
\text { and other incentive benefits } \\
\text { for employees. }\end{array}$ \\
\hline 9. Sigler (1999) & \multicolumn{3}{|c|}{$\begin{array}{l}\text { He found that Talent management practices such as incentive based pay may be the } \\
\text { answer to retain highly talented people. }\end{array}$} \\
\hline
\end{tabular}




\begin{tabular}{|c|c|c|c|}
\hline $\begin{array}{l}\text { 10. Byars \& Rue } \\
(2000)\end{array}$ & \multicolumn{3}{|c|}{$\begin{array}{l}\text { From their research they found that good talent management in form of proper } \\
\text { employee reward system affects the job satisfaction. }\end{array}$} \\
\hline $\begin{array}{l}\text { 11. Walter, Stephen, } \\
\text { \& Jonathan (2009) }\end{array}$ & $\begin{array}{l}\text { They studied talent } \\
\text { management across } 28 \\
\text { Indian firms involving } \\
4811 \text { professional-level } \\
\text { employees. }\end{array}$ & $\begin{array}{l}\text { Research objective was } \\
\text { to find out the reasons } \\
\text { behind employee } \\
\text { turnover and its } \\
\text { relationship with TM } \\
\text { practices. }\end{array}$ & $\begin{array}{l}\text { They identified intrinsic } \\
\text { rewards as a critical } \\
\text { element in employee } \\
\text { retention, satisfaction and } \\
\text { career success. }\end{array}$ \\
\hline
\end{tabular}

\section{B. Studies related to TM and its Impact}

\begin{tabular}{|c|c|c|c|}
\hline Study By & Conducted At & Research Aim & Research Outcome \\
\hline $\begin{array}{l}\text { 1. Singh \& } \\
\text { Sabbarwal (2010) }\end{array}$ & $\begin{array}{l}\text { An exploratory research } \\
\text { based on the sample study } \\
\text { of } 70 \text { respondents from } \\
\text { private and public sector } \\
\text { employees. }\end{array}$ & $\begin{array}{l}\text { To study the role of } \\
\text { Talent in leveraging the } \\
\text { company's intangible } \\
\text { assets such as, brand } \\
\text { names, innovation, } \\
\text { creativity, and } \\
\text { entrepreneurship. }\end{array}$ & $\begin{array}{l}\text { He identified certain } \\
\text { factors that constitute } \\
\text { Talent \& measures it too } \\
\text { like; Communication, } \\
\text { organizing, creativity \& } \\
\text { accountability, analysis \& } \\
\text { probing, action and } \\
\text { leadership quotient. }\end{array}$ \\
\hline $\begin{array}{l}\text { 2. Boudreau \& } \\
\text { Ramstad (2005) }\end{array}$ & \multicolumn{2}{|c|}{$\begin{array}{l}\text { They defined the term Talentship, which refers to } \\
\text { logical, reliable and consistent framework leading to } \\
\text { enhanced and accurate decisions about key resources. }\end{array}$} & $\begin{array}{l}\text { Proposed a direct } \\
\text { correlation } \\
\text { existing between the } \\
\text { evolution of Talentship in } \\
\text { an organization and overall } \\
\text { organizational success and } \\
\text { growth. }\end{array}$ \\
\hline $\begin{array}{l}\text { 3. Ordonez de } \\
\text { Pablos (2004) }\end{array}$ & $\begin{array}{l}\text { An exploratory research } \\
\text { done on } 39 \text { organizations } \\
\text { of different industries. }\end{array}$ & $\begin{array}{l}\text { To study the most } \\
\text { significant impact on } \\
\text { orgn. From the human } \\
\text { capital, relational capital } \\
\text { and structural capital. }\end{array}$ & $\begin{array}{l}\text { He identified the human } \\
\text { Capital (Talent) as the vital } \\
\text { tool for achieving } \\
\text { sustainable competitive } \\
\text { advantage. }\end{array}$ \\
\hline 4. Hills (2009) & $\begin{array}{l}\text { He conducted an } \\
\text { exploratory study in a } \\
\text { company named, EMI in } \\
\text { Music industry. }\end{array}$ & $\begin{array}{l}\text { In the time of recession, } \\
\text { how talented employees } \\
\text { can be retained. }\end{array}$ & $\begin{array}{l}\text { Through Talent Audit, } \\
\text { Talented employees were } \\
\text { identified \& were retained } \\
\text { through Bonuses \& } \\
\text { progressive opportunities. }\end{array}$ \\
\hline 5. Wyatt (2003) & \multicolumn{3}{|c|}{$\begin{array}{l}\text { Through his research study, he found that companies having a vigorous approach in } \\
\text { building internal leadership capacity through talent management practices such as } \\
\text { succession planning, are having better financial returns, growth in net income and } \\
\text { market share. }\end{array}$} \\
\hline $\begin{array}{l}\text { 6. } \mathrm{CCH} \\
\text { Incorporated (1995) }\end{array}$ & \multicolumn{2}{|c|}{$\begin{array}{l}\text { An exploratory research was conducted to identify the } \\
\text { Financial impact on Talent management practices. }\end{array}$} & $\begin{array}{l}\text { Research findings says that } \\
\text { four financial measures } \\
\text { namely; market/book value, } \\
\text { Productivity Index, Market } \\
\text { value and sales increases } \\
\text { with the quality of talent } \\
\text { management Practices. }\end{array}$ \\
\hline
\end{tabular}




\begin{tabular}{|l|l|l|}
\hline 7. Huselid (1995) & $\begin{array}{l}\text { He conducted a primary research study to trace out the } \\
\text { impact of Talent management practices on economic } \\
\text { returns of the US firms. }\end{array}$ & $\begin{array}{l}\text { He found that top 15 } \\
\text { companies in terms of using } \\
\text { good talent management } \\
\text { practices registered } 7 \% \\
\text { increase in sales, } \$ 3800 \\
\text { increase in profit per person } \\
\text { and increase of } \$ 18,600 \text { in } \\
\text { market value per employee. }\end{array}$ \\
\hline
\end{tabular}

C. Studies related to developing TM indices

\begin{tabular}{|l|l|l|l|}
\hline \multicolumn{1}{|c|}{ Study By } & \multicolumn{1}{|c|}{ Conducted At } & \multicolumn{1}{c|}{ Research Aim } & \multicolumn{1}{c|}{ Research Outcome } \\
\hline $\begin{array}{l}\text { I. Deborah \& Kathy } \\
\text { (2009) }\end{array}$ & $\begin{array}{l}\text { They conducted } \\
\text { research for Real } \\
\text { Estate. }\end{array}$ & $\begin{array}{l}\text { To bring out the strategies } \\
\text { for attracting and retaining } \\
\text { talent in real estate industry. }\end{array}$ & $\begin{array}{l}\text { They proposed a TM } \\
\text { framework which outlined } \\
\text { five key elements namely } \\
\text { attracting, selecting, } \\
\text { engaging, developing and } \\
\text { retaining. }\end{array}$ \\
\hline 2. Derry (2008) & $\begin{array}{l}\text { She conducted a } \\
\text { research for } \\
\text { Hospitality and } \\
\text { Tourism Industry. }\end{array}$ & $\begin{array}{l}\text { To study the role of Talent } \\
\text { Management in reducing } \\
\text { employee Turnover in the } \\
\text { same industries. }\end{array}$ & $\begin{array}{l}\text { She recommended the } \\
\text { strategies like flexible } \\
\text { working hours, good role } \\
\text { models at workplace, sound } \\
\text { recruitment cum training } \\
\text { opportunities and company } \\
\text { family friendly work } \\
\text { policies for retaining talent. }\end{array}$ \\
\hline $\begin{array}{l}\text { 3. Jones \& } \\
\text { Newhouse (2004) }\end{array}$ & $\begin{array}{l}\text { US, New York City } \\
\text { and Chicago, on } \\
\text { employees working in } \\
\text { manufacturing } \\
\text { industries. }\end{array}$ & $\begin{array}{l}\text { To investigate the } \\
\text { relationship between talent } \\
\text { management indices and } \\
\text { personality traits. }\end{array}$ & $\begin{array}{l}\text { With the help of double } \\
\text { cross validation strategy, } \\
\text { they concluded that the } \\
\text { Talent Management indices } \\
\text { like; leadership potential, } \\
\text { leadership style, sales } \\
\text { potential, creative potential } \\
\text { etc. can be predicted from } \\
\text { narrow personality traits. }\end{array}$ \\
\hline
\end{tabular}

D. Studies related to TM Challenges

\begin{tabular}{|c|c|c|c|}
\hline Study By & Conducted At & Research Aim & Research Outcome \\
\hline 1. Nair (2009) & \multicolumn{2}{|c|}{$\begin{array}{l}\text { He conducted a research to identify the challenges } \\
\text { being faced in managing the Organizations' Talent } \\
\text { that leads to organization's success. }\end{array}$} & $\begin{array}{l}\text { His findings are as under: } \\
\text { 1. Attracting highly qualified } \\
\text { candidates } \\
\text { 2. Identifying and developing } \\
\text { talent for key positions in } \\
\text { the organization } \\
\text { 3. Retention of key performers } \\
\text { 4. Maintaining high levels of } \\
\text { employee engagement } \\
\text { 5. Optimizing compensation } \\
\text { to match organizational } \\
\text { objectives }\end{array}$ \\
\hline
\end{tabular}




\begin{tabular}{|l|l|}
\hline 2. Erickson (2008) & $\begin{array}{r}\text { Through his research, he found out the following Talent Management Challenges: } \\
\text { 1. Attracting and retaining enough employees at all levels to meet the needs } \\
\text { of organic and inorganic growth }\end{array}$ \\
2. Creating a value proposition that appeals to multiple generations \\
3. Developing a robust leadership pipeline \\
4. Rounding out the capabilities of hires who lack the breadth of necessary \\
for global leadership. \\
5. Transferring key knowledge and relationships \\
6. Stemming the exodus of Gen X'ers from corporate life \\
7. Redesigning talent management practices to attract and retain Gen Y's \\
8. Creating a workplace that is open to Boomers in their "second careers." \\
9. Overcoming a "norm" of short tenure and frequent movement. \\
10. Enlisting executives who don't appreciate the challenge.
\end{tabular}

\section{LITERATURE REVIEW}

\subsection{Talent}

Talent is a collective knowledge, skills, abilities, experiences, values, habits, and behaviors of the employees (Schiemann, 2014). Further, Cooke et al. (2014), Stuart-Kotze and Dunn (2008), Frank and Taylor (2004) revealed that talent is about an outstanding characteristics of human beings to do something different or a higher order of difficulty and complexity in the current and future time period. It comprises special groups such as senior leadership, middle-level employees with leadership potential, key contributors or technical experts and entry-level employees with leadership potential (Elegbe, 2010). Zhang and Bright (2012) gave new characteristics of talented employees in term of 'guanxi', which revealed that talented employee should have trust, shared vision, and harmonious relationship with colleagues, and external social network for future benefits. But, according to Elegbe (2010), Stewart (2008), Clake and Winkler (2006) talent is related to situation-specific characteristics that cannot be defined without the relationship with the environment (social and cultural) and the individual context because it can only be understood to exist through behavior.

However, TM practices have become the most critical aspect and common term in the strategic and managerial glossary of every type of organization for managing its talent pool (Saxena, 2013). Now, the question arises: what comprises talent or who should be considered as talent in the organisations? (Iles, 2013; Tansley, 2011), which is still debatable term (Dries, 2013; Thunnissen et al., 2013; Gallardo-Gallardo et al., 2012; Tansley, 2011; Lewis and Heckman, 2006). According to 19th century authors, talent emerges from learning as well as abilities and knowledge in at least one field of human endeavour (Heller et al., 2000; Gagne, 1999). But, 20th century authors (e.g., Meyers and Woerkom, 2014; Dries, 2013; Swailes, 2013; Tansley and Tietze, 2013; Thunissen et al., 2013; Gallardo-Gallardo et al., 2012; Schuler et al., 
2011; Makela et al., 2010; Becker et al., 2009; Collings and Mellahi, 2009; Lewis and Heckman, 2006; Ashton and Morton, 2005) viewed it in two different ways: the first approach viewed talent in a more general, universal, and inclusive way, which focussed on all the employees and allows them to

explore their potential; whereas the second approach viewed talent as exclusive approach in terms of high performers and high potential, which is based on segmentation or differentiation of a small segment according to skill, knowledge, performance of the workforce. It concentrated only on those employees in the organisation, who are exceptional, A-performer (above-average abilities), and applies their abilities to achieve excellent organisational performance (Swailes, 2013).

In conclusion, talent comprises individual characteristics that come from natural ability, which is enhanced through opportunities to learn, grow, and systematic development of skills, competencies, and knowledge. These characteristics vary according to the organisational environment (internal and external), work/job type, and across time (Iles, 2013; Thunnissen et al., 2013; Gallardo-Gallardo et al., 2012; Tansley, 2011; McCauley and Wakefield, 2006; Ashton and Morton, 2005). It is recognized as a stable entity, which requires implementation of TM practices for talent identification, selection, development, and gaining experiences (Meyers and Woerkom, 2014). In researcher's perception, only exclusive approach (based on talented employees only) is a better fit with the original contributions on TM practices rather than inclusive approach. Thus, researcher defines talent as,

"The high performers and high potential employees, who have a sharp strategic mindset, managerial, communication, and functional skills along with experience, commitment and contribution behaviour, which result in outstanding performance."

\subsection{Talent management: a new strategic philosophy and practice}

The term 'talent management' as concluded by academicians, researchers, and practitioners refers to the activities related to recruitment, selection, development, and retention of employees. Lewis and Heckman (2006) concluded that despite the considerable debate over the last decade in academic literature, TM is still in its infancy stage, which is too narrow and onedimensional approach with limited practices and activities. It lacked a clear and consistent definition, rhetoric (language), and scope, which has been confirmed by Iles et al. (2010), Collings and Mellahi (2009), Sumardi and Othman (2009). However, Collings et al. (2011) concluded that TM has moved from infancy to adolescence stage, which is a more balanced or pluralistic approach due to added (new) perspectives, such as stakeholder theory, multiple goals, and an extended consideration of HR practices (Cooke et al., 2014; Thunnissen et al., 2013). Recently it has also been recognized in the form of different concepts, philosophies, and practices like human capital management (HCM), human resource information systems (HRIS) or human resources management systems (HRMS) or HR modules (Bryan et al., 2006).

The foremost contribution by TM is the willingness of the system to analyze and bridge the gap between talent demand and talent supply by determining the weakness and strength of the employees and management as well as by the strategic flow of talent through an organization, which helps to connect individual goals to organizational goals and workforce strategies to business strategies (Kaur, 2013; Hilal, 2012; Iles, 2008). Thunnissen et al. (2013), Valverde et al. (2013), Garrow and Hirsh (2008), Figliolini et al. (2008) defined TM as a process which includes a complete and interrelated set of organizational activities such as identifying, selecting, developing, and retaining the best employees as well as building their potential for the most strategic positions, and assisting them in formulating the best use of strengths in order to gain their engagement and contribution, which ultimately contribute to organizational benefits (Nankervis, 2013; Bano et al., 2010; Davies and Davies, 2010; Beechler and 
Woodward, 2009; Hughes and Rog, 2008; Ready and Conger, 2007; Chugh and Bhatnagar, 2006; McCauley and

Wakefield, 2006). These activities start with the identification of most suitable individuals and end with retaining them (Silzer and Church, 2010; Lockwood, 2006).

It encompasses all HR processes, administration, and technologies for talent optimization and utilisation (Schiemann, 2014; Schweyer, 2004). On same lines, Powell and Lubitsh (2007) characterized five major perspectives of TM, i.e.,

- Process (for optimized people within an organisation)

- Cultural (more of a mindset than a set of activities)

- Competitive approach (by identifying talented employees, finding out what they want, and giving it to them)

- Developmental (accelerated development paths for the highest potential employees), and

- Identifying human resource planning (assign right people to the right jobs at the right

- Time and doing the right thing).

Business Process Management Forum (2007) (cited in Nankervis (2013)) viewed TM as 'Soft TM' that focus only on "Hearts and Minds of people" rather than their 'Bodies' (as 'Hard TM'). Cappelli (2008a) criticised the above perceptions about TM by stating that TM exists only to support the organisation's overall objective, which essentially amounts to making money rather than developing, succession planning, and retention.

Table 2 shows the definitions of TM by various authors.

\begin{tabular}{|l|c|}
\hline \multicolumn{1}{|c|}{ Definition of talent } & Source \\
\hline $\begin{array}{l}\text { "Talent = competence (knowledge, skills and values required for todays' } \\
\text { and tomorrows' job; right skills, right place, right job, right time) } \\
\text { commitment } \\
\text { (willing to do the job) } \times \text { contribution (finding meaning and purpose in } \\
\text { their job)" (p. 60) }\end{array}$ & $\begin{array}{c}\text { Ulrich \& Smallwood } \\
\text { (2012) }\end{array}$ \\
\hline $\begin{array}{l}\text { "An individual's skills and abilities (talents) and what the person is } \\
\text { capable of doing or contributing to the organization." (p. 14) }\end{array}$ & $\begin{array}{c}\text { Silzer \& Dowell } \\
\text { (2010) }\end{array}$ \\
\hline $\begin{array}{l}\text { A set of competencies that, being developed and applied, allow the person } \\
\text { to perform a certain role in an excellent way. (p 22) }\end{array}$ & $\begin{array}{c}\text { González-Cruz, Martínez-Fuentes, \& } \\
\text { Pardo-del-Val } \\
\text { (2009) }\end{array}$ \\
\hline $\begin{array}{l}\text { "Essentially, talent means the total of all the experience, knowledge, } \\
\text { skills, and behaviors that a person has and brings to work." (p. 46) }\end{array}$ & $\begin{array}{c}\text { Cheese, Thomas, \& Craig } \\
\text { (2008) }\end{array}$ \\
\hline $\begin{array}{l}\text { "Talent equals competence (able to do the job) times commitment (willing } \\
\text { to do the job) times contribution (finding meaning and purpose in their } \\
\text { work)" (p. 3) }\end{array}$ & $\begin{array}{c}\text { Ulrich } \\
(2007)\end{array}$ \\
\hline $\begin{array}{l}\text { "Talent can be considered as a complex amalgam of employees' skills, } \\
\text { knowledge, cognitive ability and potential. Employees' values and work } \\
\text { preferences } \\
\text { are also of major importance." (p. 2) }\end{array}$ & Tansley, Harris, Stewart \& Turner \\
\hline $\begin{array}{l}\text { "Talent should refer to a person's recurring patterns of thought, feeling, or } \\
\text { behavior that can be productively applied." (p. 21) }\end{array}$ & \begin{tabular}{l} 
(2006) \\
\hline $\begin{array}{l}\text { "(...) superior mastery of systematically developed abilities or skills" (p. } \\
\text { 67) }\end{array}$
\end{tabular} \\
\hline
\end{tabular}


In conclusion, the researcher has generated exclusive definition of TM after studying and critically examining the literature on this concept (such as Festing et al., 2013; Vaiman and Collings, 2013; Valverde et al., 2013; Stahl et al., 2012; Areiqat et al., 2010; Davies and Davies, 2010; Horvathova and Durdova, 2010; Iles et al., 2010; Collings and Mellahi, 2009; Grobler and Diedericks, 2009; Cappelli, 2008b; Figliolini et al., 2008; Heinen and O'Neill, 2004), which is:

"It as an organizational activity, which starts with the systematic identification of key positions (through talent review and talent evaluation), creation of talent pool for these positions (through internal talent segmentation and talent nomination), followed by succession planning, development, and retention of the talent, i.e., the high performers, who help in achieving organization's strategic priorities as well as sustainable competitive advantage."

Hence, it is conceptualized that TM is a multidimensional process, which is more inclined towards the TM cycle of internal employees rather than the external ones.

\subsection{Traditional and modern views about talent management}

Despite a wide popularity of TM, some authors, researchers, and practitioners apparently revealed that it is somewhat 'faddish' or "old wine in a new bottle" or old practices of HRM or rebranding of HRM (Stewart, 2008; Lewis and Heckman, 2006; Mucha, 2004). It contains fairly traditional HRM activities such as recruitment, selection, training and development, career development, performance management, and appraisal and reward (Lewis and Heckman, 2006). Further, Cooke et al. (2014), Iles et al. (2010), 228 J. Jyoti and R. Rani Cappelli (2008a), Bhatnagar (2007), McCauley and Wakefield (2006) and Schweyer (2004) also viewed TM as a collection of old HRM practices including sourcing, screening, workforce planning and replacement planning, succession and career planning, assessment centres, and 360o degree feedback, which are not like other 'fashionable' HR functions. Further, Lewis and Heckman (2006) also added that talent equals to human capital; so TM equals to HRM. Various authors have used TM and HRM practices simultaneously (Keegan and Boselie, 2006).

Earlier authors concentrated only on a single aspect of TM, which was fairly similar to HRM practices. But, the modern and the multiple aspect approach of TM is distinct from traditional HRM practices. Initially, Huselid et al. (2005) differentiated TM from other HR approaches and focused on identifying the core positions that should be filled up with 'A performers'. Further, Iles et al. (2010), Collings and Mellahi (2009), Blass et al. (2006) viewed that the main and collective focus of TM practices is only on high potential and high-performing employees, which is helpful for organizations to attract, acquire, recruit, employ, and retain them to achieve success (Piansoongnern et al., 2011; Areiqat et al., 2010; Iles et al., 2010). These practices are designed to find out and to solve various current and future HR challenges and to defuse the traditional HRM's weaknesses too (Fawzi, 2013; Schuler et al., 2011; Iles et al., 2010; Piansoongnern and

Anurit, 2010; Lewis and Heckman, 2006; Frank and Taylor, 2004). The attraction, identification, succession planning, development, engagement, and the retention of talented people are the key practices of TM, which supply the future (high-performer) leaders by focussing on diversity and knowledge beyond the traditional HRM practices (Kaur, 2013; Ruwaili et al., 2013; Vaiman and Collings, 2013; Zhang and Bright, 2012; Bano et al., 2010; Vaiman, 2010; Collings and Mellahi, 2009; Tansley and Sempik, 2008). Further, TM highlights the key resource's (talent) ability to adopt and/or modify the opportunities in the business and career environment (Barney, 1991). Now, many organisations are using a structured, stagebased hierarchical approach for TM like;

Staggered or classified process (Tansley and Tietze, 2013). So, it is more than yet another or traditional HR processes/strategies/practices. 
In the second perspective, some authors viewed TM as an integrated, strategic, and technology-enabled approach to HRM, with a particular focus on recruitment, professional development, diversity, retention, advanced leadership development, performance management, workforce planning, culture development and succession planning especially for those, who are identified as high potentials (Kaur, 2013; Piansoongnern et al., 2011). Further, TM has strengthened its theoretical foundation by integrating HRM and organisational theories such as, analysis management objects model, career management, contingency theories, decision-making theories, resource based view, human capital, and social-technical systems theory (Thunnissen, 2013, p.1758; Collings and Mellahi, 2009).

After reviewing the above literature, researcher concludes that TM is a new and different approach from traditional HRM practices. These practices are more strategic, future oriented, and continuous in nature, which help in achieving overall corporate strategic goals (Vaiman and Collings, 2013; Lewis and Heckman, 2006; Schweyer, 2004). TM always focusses on talented or high-performers or high-potential staff members (through talent segmentation) rather than management functions and common employees (Kaur, 2013; Iles et al., 2010; Snell, 2007). Additionally, HR demands that organizations need to transform traditional HR practices (like staffing and recruitment process) into SHRM (such as TM practices) through talent retention, identification, and attraction process for achieving organizational and employeesrelated benefits that help in succeeding in the hyper-competitive and increasingly complex global environment (Areiqat et al., 2010; Yue Ngo et al., 2008).

\section{CONCEPTUAL FRAMEWORK}

Review of literature helped us to identify major TM practices viz., talent identification, succession planning, talent development, and talent retention. In the conceptual framework, the researcher has proposed two models. The first model identifies the major TM practices, which is reflective in nature*. In this model, inter-relationship between different practices/dimensions of TM will also be examined (Figure 1).

Literature also revealed that for managing the talented employees, organizations have to create its own unique TM strategy and this talent strategy must be aligned with an organizational strategy (Heinen and O'Neill, 2004). Beside this, the effective TM practices also require strong leadership/management commitment (White, 2009; Handfield-Jones et al., 2001) to implement TM practices at the strategic level (Chhabra and Mishra, 2008). By the contribution of all level management, organization can establish explicit guiding principles for acquiring, managing, developing, rewarding, and retaining talent to drive business results and performance (Heinen and O’Neill, 2004; Mucha, 2004). Further, organizations are also trying to establish themselves as a brand, known as 'employer branding' for reducing the talent gap by talent attraction, identification, and retention (Gehrels and Looij, 2011; Piansoongnern et al., 2011; Priyadarshi, 2011; Lockwood, 2010; Mandhanya and Shah, 2010; Chhabra and Mishra, 2008; Mosley, 2007).

No doubt, TM practices help not only to overcome a talent shortage, but also deliver financial results to win the approval of all stakeholders, to increase productivity and the capability (Janardhanam et al., 2011). Strong talent in the company also has a positive impact on business outcomes such as company profit, market value, and greater shareholders' value, return on assets and return on equity (Bethke-Langenegger et al., 2011; Silzer and Dowell, 2010; Heinen and O'Neill, 2004). Besides, it also has nonfinancial impact on the performance at organizational as well as employee level such as organizational commitment, employee performance, customer satisfaction, reduces time of replacement, job satisfaction, and company's attractiveness (Areiqat et al., 2010; Bano et al., 2010; Bethke-Langenegger et al., 2011; Horvathova and Durdova, 2010; Mucha, 2004). 
Hence, the above literature helped in generating integrated model (Figure 2), which explains the phenomenon responsible for establishing TM practices and its impact on financial and nonfinancial performance. The theoretical model explains the impact of business strategy, management commitment, employer branding, and employee engagement on different TM practices. Further, the theoretical model also tries to establish the role of TM practices towards financial and non-financial performance at organizational and employee level.

\section{PROPOSITIONS DEVELOPMENT}

\subsection{Talent management as a multidimensional phenomenon}

TM is a multidimensional and unified process/system/strategy/practice, which covers all major key phases of an employee's life cycle in the organisation, i.e., selection, development, utilization, succession planning, performance management, and retention to enhance their performance and productivity in current positions and prepare them for higher career (Schiemann, 2014; Areiqat et al., 2010; Bano et al., 2010). In this life cycle, organization's special attention is only on their high-potential or talented employees. So, it is concluded that TM practices span the entire "talent life cycle" from talent identification to retention (Newhouse et al., 2004). This process can also be known as a 'people (talent) management system' (Wright et al., 2001) or model of personnel management (Mandhanya and Shah, 2010). Collings and Mellahi (2009) theorised that the TM process starts with systematic identification of key positions followed by the development of high potential and high performing incumbents to fill these roles and to ensure their continued commitment to the organization. Further, Davies and Davies (2010), Mandhanya and Shah (2010); Puvitayaphan (2008) have defined TM as a collection of various practices such as talent attraction, talent identification, succession planning, talent development, talent engagement, talent retention, and talent deployment, which are integrated with each other to make the TM process successful for the organization, existing employees as well as new applicants.

These practices are placed in strategic sequenced starting with talent identification (Silzer and Church, 2010; Bryan et al., 2006; Boudreau and Ramstad, 2005) where selection of applicants is for the future leadership, not for a specified position (Farashah, Nasehifar, and Karahrudi, 2011). Talent identification is held through performance appraisal, personal and organisational feedback (profile analysis and talent group awareness, self-assessment and action planning), direct comparison rating, talent segmentation, and talent nomination (Hartmann et al., 2010; Lehmann, 2009; Piansoongnern and Anurit, 2010; Silzer and Church, 2010; Edwards and Bartlett, 1983).

Once organizations have identified their best talent, the next practice is the future position

planning of identified talent according to their skills, knowledge, and competencies, which is a succession planning for long run process. The next (third) practice is development of selected talent pools through TM tools such as on-the-job experience coupled with targeted educational/learning opportunities (formal as well as informal), cross-functional training, stretched assignments, challenging tasks, career development, and increased support through coaching and mentoring (Farashah et al., 2011; Yarnall, 2011; Areiqat et al., 2010; Hartmann et al., 2010; Lehmann, 2009; Sumardi and Othman, 2009; Chhabra and Mishra, 2008; Greer and Virick, 2008; Puvitayaphan, 2008; Heinen and O'Neill, 2004; Michaels et al., 2001). The last and critical practice of TM process is "talent retention". It can be controlled through performance-based pay, training, challenging work, intrinsic motivations, career development, and giving benefits before demand (Piansoongnern et al., 2011; Lehmann, 2009; Connors et al., 2008; Jamrog,2004). On the basis of the above review, researcher develops the first proposition:

P1: Talent management is a multidimensional construct comprising talent identification, succession planning, talent development, and talent retention. 
The various practices of $\mathrm{TM}$ as identified above are interrelated as implementation of one is dependent on the other. According to Hills (2009) and Bhatnagar (2007), under the TM practices, succession planning (SP) is most imperative and updated business strategies, which integrates all major practices of TM together to build and manage talent pool effectively. Hartmann et al. (2010), Lewis and Heckman (2006) compared the management of internal talent pools (TM) with succession or human resource planning.

On the same line, Rothwell (2010), Greer and Virick (2008) stated that SP requires early identification/selection of talent through critical indicators of success, i.e., learning and learning agility (Lombardo and Eichinger, 2000). Further, it also requires professional development opportunity for identified talent pools through development programmes, individual career development plans, 360-degree feedback, executive coaching, mentoring, networking, job assignments, and action learning (Groves, 2011; Piansoongnern et al., 2011; Frase-Blunt, 2003). Additionally, Pollit (2009) described succession planning as a tool to develop the leaders for future and to review the talent regularly for their retention purpose. The implementation of succession planning automatically increases the satisfaction level of future leaders, which is a necessity for retention (Perrin, 2005). Same views have been extended by Golden (2005). He justified the importance of succession planning as an important tool of TM for talent retention. Hence, SP is planned and systematic effort by an organization to ensure leadership continuity in key positions, retain and develop intellectual and knowledge capital for the future benefits (Rothwell, 2010).

Further, retaining high-calibre employees in today's competitive labour market challenges the organisations to manage and develop talent effectively at all levels. Bano et al. (2010) viewed that the employees who feel that they are growing and developing in an organization are more likely to stay for a long period of time. Training and development programs encourage the movement across the business and reduce turnover of talented employees (Yarnall, 2011; Lockwood, 2007). Performance-based pay, career development, investment in management, enhancing leadership skills are the practices adopted by the organizations for talent retention (Areiqat et al., 2010; Hartmann et al., 2010). Cappelli (2008b) indicated that the lack of internal development of talent has increased the demand for outside hiring, which in turn causes retention problems of talented employees. So, firms with superior training programs are likely to experience lower staff turnover than companies which lack staff development opportunities (Fey et al., 2000). On the basis of the above literature review, the next propositions are:

P2 (a): Succession planning is significantly related with identification, development, and retention of talented employees.

P2 (b): Higher the talent development better is the talent retention capacity of an organization.

\section{ANTECEDENTS OF TALENT MANAGEMENT PRACTICES}

\subsection{Business strategies and talent management practices}

TM practices are essential for achieving the organization's goals, but it also requires strategic attention and appropriate resources like sales, marketing, or production $232 \mathrm{~J}$. Jyoti and R. Rani

Strategies (Puvitayaphan, 2008). So, the foremost requirement is strategic alignment of business strategy with TM practices (Horvathova and Durdova, 2010). Exclusive business strategies for managing talent need to be developed to meet the business goals, which are also helpful in differentiating the organization in the marketplace (Piansoongnern et al., 2011; Heinen and O'Neill, 2004). In the ninth century, this alignment has been suggested in the "War for Talent" (Chambers et al., 1998), which emphasized the need to "elevate talent management to a burning corporate priority" (p.46). Similarly, survey by Morton (2005) revealed that one 
of the most important internal success factors for TM is its alignment with strategic business goals by making it as an integral part of the business strategy (McDonnell, 2011; Lockwood, 2006). On the same lines, Horvathova and Durdova (2010) revealed that the majority of organizations using TM practices recognised the necessity of the existence of managing talented individuals' strategy along with organisation's overall business strategy.

Hence, business strategy is the first step and a building block for employing TM practices in an organisation (Silzer and Dowell, 2010; Grobler and Diedericks, 2009). This strategic integration (fully or partially) becomes a core element of TM to assess, attract, identify, develop, and retain high potentials (Iles et al., 2010; Mucha, 2004) for best utilisation of tools and processes to deliver TM solutions (Bano et al., 2010).

Additionally, business strategy is also linked with SP, which is very essential to obtain requisite set of skills for the future and to grow or expand into new markets (Farashah et al., 2011). Greer and Virick (2008) explained that for identifying the range of competencies and for designing the developmental experiences required by the successor, succession planning must be integrated with business strategies. This process should be continuous and flexible because the competencies for key personnel are likely to change in the future. In contrast, scholars like Burkus and Osula (2011); Martin and Schmidt (2010) critically examined the link between TM and strategy. They explored the possible negative effects of TM after being aligned with the business strategic goals. Hence, the next proposition is:

P3: Business strategies exercise significant impact on talent management practices viz., talent identification, succession planning, talent development, and talent retention.

\subsection{Management commitment and talent management practices}

$\mathrm{TM}$ always requires strong commitment from the top management team and board members to face economic, political, and social challenges (Groves, 2011; Handfield- Jones et al., 2001). In support of this, much of the academic work on TM has necessitated that TM issues must be put on top management's agenda (Schuler et al., 2011; Sandler, 2006). In this context, Conaty and Charan (2010) explored that the first principle of managing TM is ensuring the support of an enlightened leadership team, starting with the CEOs. These enlightened CEOs recognise that their top priority and legacy issue is building and deploying the talent for the future (Conaty and Charan, 2010). Hence, they act as a champion or facilitator or change agent for introducing and providing the direction for TM programmes (Wahjosoedibjo, 2009; Handfield-Jones et al., 2001). Similarly, Morton (2005) also stated that a "talent mindset must cascade from the top, with the CEO as the driver" (pp.9), who should devote at least $20-50 \%$ of their time on TMrelated issues (Economist Intelligence Unit, 2006). Further, Horvathova and Durdova Exploring talent management practices: antecedents and consequences 233 (2010), Wahjosoedibjo (2009), Farley (2005) stressed for active involvement of top executives in the TM strategy for its success. Proper utilization of TM by the top management members is considered as one of the key criteria for TM success.

The implementation of talent and competency-based management practices is not the sole responsibility of top management as it is practiced at all levels in the organization. So, all levels of hierarchy have to participate in this management process (Bano et al., 2010). Further, Grobler and Diedericks (2009) also revealed that top management also required consultancy and advisory services of human resource professionals and experts at the time of implementing TM practices. Conaty and Charan (2010) also revealed that TM issues aren't HR issues anymore. They are now line management issues. So, there is need of a profound shift. Therefore, HR managers must consistently communicate with line managers (having talent mindset) or executives of all levels at the time of decision making regarding the management of talented people. According to Heinen and O'Neill (2004) and Mucha (2004), all level of 
leaders/managers create a shared set of leadership values around the TM and establish explicit guiding principles for acquiring, managing, developing, and rewarding talent to drive business results and performance. Further, top management, senior leadership team, HR managers and line managers' commitment also have clear threshold requirements for succession planning (Greer and Virick, 2008) especially for identifying and analysing key jobs, creating and assessing candidates, and selecting the right individuals who will fill up the key positions (Farashah et al., 2011).

Additionally, Diamond (2006) exposed that management commitment, like any other organisational-wide programme is critical for successful implementation of the SP. Without the management support, SP is not executable even if design phase is accurate (Diamond, 2006). Hence, Puvitayaphan (2008) viewed that top executives, line managers, department chiefs, and other heads must cooperate and participate in implementation of TM practices, starting from the identification of employees followed by succession planning, development, and retention of talent personnel. On the other side, Ready and Conger (2007) draw attention towards the difficulty in keeping the commitment of senior executives, who often have other competing priorities. Though senior executives have other important priorities, they cannot ignore the commitment towards TM due to its important outcomes. Hence, next proposition is:

P4: Management commitment is must for successful implementation of talent management practices viz., talent identification, succession planning, talent development, and talent retention in an organization.

\subsection{Employer branding, talent identification, and talent retention}

Employer branding (EB) process focusses on attraction, acquisition, and retention of talent pools (Tansley, 2009). During recession or a growing economy, successful TM process always requires an effective EB, which is pre-installing formalities for employees (Lockwood, 2010). Dell and Hickey (2002) highlighted the concept of "employer of choice" (external marketing of the employer brand) for the development of a unified and consistent TM strategy for attracting talent pools. Organization with strong EB strategy is able to reduce the cost of talent acquisition, improve employer-employee relations, and increase talent retention as compared to firms with weaker employer brands (Ritson, 2002). Besides, its strategic focus is on attracting, hiring, and retaining talent.

It is also helpful in talent identification in a highly competitive market (Priyadarshi, 2011). It ensures strategic identification of employees within the organisation apart from traditional recruitment process, which creates only huge databases (Lockwood, 2010). Moroko and Uncles (2008) viewed that EB can positively or negatively impact employees' expectations and experiences of the firm at every stage of their employment lifecycle, from initial attraction or identification to employment and retention. Priyadarshi (2011) revealed a positive relationship between intention to leave and EB because employees found the work monotonous and underutilization of their capabilities.

In comparison, Gatewood et al. (1993) found that corporate image is a significant predictor of decisions to pursue employment and management of talent within the company. Further, Sutherland et al. (2002) also advocated that EB communicates its corporate identity and reputation to current and potential employees for attracting and retaining skilled employees (internal marketing of EB), which has been cemented by Backhaus and Tikoo (2004). According to Hewitt Associates (cited in Backhaus and Tikoo, 2004, p.502), EB refers "to providing a coherent framework for management to simplify and focus priorities, increase productivity, and improve recruitment, retention, and commitment". Research in India by Tymon et al. (2010) has revealed a negative relationship between EB (like pride in the 
organization and perception of the employer as being socially responsible) and intention to leave.

The above review of literature answers the questions put forth by Backhaus and Tikoo (2004): Do firms using EB experience improved recruitment outcomes; Is employee retention improved? Hence, next proposition is:

\section{P5: Employer branding leads to better talent identification and talent retention.}

\subsection{Employee engagement and talent retention practice}

Talent retention is an important issue and Morgan (2008) viewed that companies should take this eriously and survey what they could do to retain top talent. In this context, Bhatnagar (2007) suggested that employee engagement is an important tool for reducing talented employees' turnover; same by Kelleher (2011), Stairs et al. (2006). Further, Lockwood and Ansari (1999) suggested that to generate strong commitment and loyalty among the young recruits, there should be a satisfactory workplace environment for employee engagement, which will reduce turnover and increase customer loyalty and stakeholder value (Ram and Prabhakar, 2011). To promote a culture of engagement, HR leaders guide the way to design, measure, and evaluate realistic workplace policies and practices that help in attracting and retaining talent with the skills and competencies required for growth and sustainability (Lockwood, 2007). Similarly, Schaufeli and

Bakker (2004) also found a negative relationship between engagement and turnover intention. Further, employee engagement mediated the relationship between job resources and turnover intention. In conclusion, Glen (2006) suggested that organizations have to take a more holistic view while planning employee engagement to manage the required key elements in order to enhance motivation, attendance, and talent retention. Employee engagement through attributes like good communication between employer and employee, and career growth opportunities induce and boost confidence within employees, which helps in their retention (Lakshmi et al., 2010; Morton, 2005). On the other hand, absence of employee engagement weakens the worker's long-term Exploring talent management practices: antecedents and consequences commitment and creates difficulty in attracting, aligning, and retaining talented employees (White, 2009). Hence, we put forth the following proposition:

P6: Higher the employee engagement better is talent retention capacity of an organization.

\section{CONSEQUENCES OF TALENT MANAGEMENT PRACTICES}

\subsection{Talent management practices and financial performance}

A recent study conducted by McKinsey confirmed the strong correlation between TM practices and financial performance (Guthridge et al., 2008). Puvitayaphan (2008) viewed that organisations implement TM programmes because they have recognised that people with high performance and high potential would significantly contribute to the success of their missions and goals, both financial and non-financial, by providing the sustainable competitive advantage (Berger and Berger, 2010). Integrated TM practices help not only to overcome a talent shortage, but also deliver better financial results needed to win the approval of all stakeholders (Janardhanam et al., 2011). Furthermore, many studies reported change in operating profit, which is due to availability of qualified and talented people in the organization (Ringo et al., 2008). Talent identification (internal) has a significant impact on the competitive advantage of the firm as identified employees contribute towards the materialization of strategy and organization's economic objectives by cutting the cost of fluctuation and reducing the extra cost on new recruitment process for vacant positions (Horvathova and Durdova, 2010). Additionally, by developing skilled talent pool, organizations increase sales, improve customer 
service, stock prices, and organizational growth (Connors et al., 2008; Handfield-Jones et al., 2001). Further,

Friedman (1986) empirically proved that succession planning also affects financial performance (especially on return on investment). In same line, Bethke-Langenegger et al. (2011) also provided support for the positive impact of succession planning and talent development on company's profit, market value, and overall talent productivity.

Moreover, TM leads to cost savings through long-term proactive internal succession planning and higher retention rates (Steinweg, 2009; Tansley et al., 2007; Sebald et al., 2005). Though, Batt (2002) researched that high standard human resources practice, i.e., talent retention contribute to the firm's profitability and market value Bethke-Langenegger et al. (2011) found no effect of talent retention on financial outcomes at the company level.

In conclusion, organizations that apply TM practices such as talent identification, succession planning, talent development, and talent retention demonstrate significantly higher financial outcomes in terms of sales revenue and productivity (Kontoghiorghes and Frangou, 2009), net profit margin and earnings before interest, depreciation, and amortisation (DiRomualdo et al., 2009), return on assets and return on equity (Joyce and Slocum, 2012), or return on shareholders' value and market value (Huselid and Becker, 1998). The above literatures lead to formulation of following proposition:

P7: Implementation of the talent management practices viz., talent identification, succession planning, talent development, and talent retention lead to better financial performance.

\subsection{Talent management practices and non-financial performance}

(at organisation level)

TM practices are drivers of organizational performance, which positively affect the nonfinancial outcomes (Bano et al., 2010). It enhances employees' capability, which in turn positively affects organization effectiveness vis-à-vis, employee morale and organizational commitment (Bano et al., 2010; Mucha, 2004). There are a number of studies, which positively link TM and organizational performance (Joyce and Slocum, 2012; DiRomualdo et al., 2009; Yapp, 2009; Ringo et al., 2008; Gandossy and Kao, 2004; Huselid and Becker, 1998).

Talent identification process helps to improve organisational performance as well as contributes to the sustainable competitive advantage by mobilising the most appropriate employees (Berger and Berger, 2010; Collings and Mellahi, 2009; Boudreau and Ramstad, 2005). Though, Bethke-Langenegger et al. (2011) found no effect of succession planning on non-financial organizational outcomes, they found positive impact of talent retention on customer satisfaction. Further, talent development positively affects company attractiveness and reduces the time of replacement. The same has been highlighted by Kontoghiorghes and Frangou (2009), who established a strong association between talent retention and organizational performance. They viewed that talent retention improves co-workers' quality of performance, provides the best value to the customer, increases the ratio of technology adaptation, which has a positive impact on organizational performance (Gberevbie, 2010). Additionally, when the organizations pay special attention to the development of the best talent, it automatically improves firm's performance. In this regard, Kaplan and Norton (1996) said that the success of the organization depends mainly on people. If they have knowledge and skills, as well as opportunities for development, they will be able to work efficiently and exhibit superior performance. Therefore, next proposition is: 
P8: Talent identification, retention, and development significantly affect nonfinancialperformance (at organisation level) viz., organisational commitment, customer satisfaction, company's attractiveness, and the time of replacement.

\subsection{Talent management practices and non- financial performance}

(at employee level)

According to Horvathova and Durdova (2010), the acceptance of TM approach is positive in those organisations that cope well with the introductory phase of putting TM into practice. TM is considered as beneficial not only for organisations, but also for individual employees (Janardhanam et al., 2011; Bethke-Langenegger et al., 2011) as talent planning and development balances the needs of the organisation with the needs of the individual (Heinen and O'Neill, 2004). For instance, the effective TM practices in the organisation increases the commitment level of the employees, enhances their effectiveness, increases their productivity, and places them according to their suitability, aptitude, and interest (Bano et al., 2010; Julia and Rog, 2008; Handfield-Jones et al., 2001). It delivers skills, abilities, and capacities, which enhance the employee performance in an organisation (White, 2009). By quality identification of talent, employees are placed in appropriate positions for better utilisation of their potential, which significantly affect employee performance (Horvathova and Durdova, 2010;

\subsection{Exploring talent management practices: antecedents and consequences}

Collings and Mellahi, 2009). In conclusion, Bethke-Langenegger et al. (2011); Kontoghiorghes and Frangou (2009) revealed that talent identification, retention, development, and succession planning have positive impact on individually focussed TM strategies such as job satisfaction, motivation, commitment, work quality, qualification, trust on leaders. It also increases employee's efforts and individual contribution in the field. Further, Farashah et al. (2011) also viewed that succession planning positively affects career attitudes; it creates perception about career success and satisfaction of promotion process among employees. From a non-financial view, succession planning yields a return in the form of internal operational efficiency in variables like greater job satisfaction and higher individual and departmental performance (Garman and Glaw, 2004). So, there is strong evidence of the positive impact of TM on employee-related outcomes. Therefore, next proposition is:

P9: Talent identification, succession planning, talent development, and talent retention are significant predictors of non-financial performance (at employee level) viz., motivation, job satisfaction, employee commitment, work quality, employee performance, and trust in leader.

\section{DISCUSSION AND CONCLUSION}

There has been a great deal of interest in TM in recent years especially among academics, practitioners, and professionals. Although, much has been said about the meaning, concept, definitions, and importance of TM, nevertheless, there is a need to broaden the TM theory for future strategic decision science (Vaiman et al., 2012). The theoretical contribution of this paper is not primarily the theory of strategic human resource management, but to enhance our understanding about the importance of TM practices in today's talent demanding business environment. To our best knowledge, there is no study that has explored together the TM practices, their predictors, as well as outcomes. Hence, this study provides one of the first conceptual model which shows antecedents and consequences of TM practices and makes a number of noteworthy contributions to this new and emerging area that help to survive in the competitive environment.

It is attempted to illuminate the area of the TM construct and provided a strategic definition for developing a measure of the construct. We have identified TM practices and proved that 
these are different from traditional HRM practices and we theoretically proved that TM is a multidimensional process. Second, interrelationships were explored among the practices of TM, which are used for proper utilisation and management of potential employees. Third, major contribution of our paper is identification of four factors, which are very imperative for practising TM practices among diverse workforce in the organisation. Lastly, we explored the impact of TM practices on financial performance and non-financial performance at organisational as well as employee level.

Our propositional conceptual and integrative framework represents efforts to build foundation for the systematic development of the theory of TM. Finally, our understanding suggests that before implementing TM practices, organisations have to append these practices into their business strategic goals. By this strategic alignment, management at various levels (e.g. top management, middle management, and lower management) will become conscious about their authority and responsibility towards TM practices. This strategic commitment of all levels of management is helpful in successful implementation of all practices in a healthier and prolonged way. Further, organisational image created by employers/managers play most vital and unique role in managing talented workforce as compared to above two factors, which may be accommodated for managing common employees. EB is one major cause that affects not only talented employees' choice towards the organisation, but also differentiates one organisation from another. Additionally, engaged employees are also more likely to have a high-quality role in overseeing TM practices, especially with talent retention.

Successful implementation of TM practices yields a sustainable competitive advantage because ideas generated by high potential employees are exclusive and inimitable, which generate financial benefits such as high profit ratio, increase in market shares, return on investment, return on shareholders' value, and enhances goodwill of the organisation. These outcomes are possible by the strategic mindset of talented and high potential employees as they always believe in and strive to perform incredibly beyond the competitive market. Besides, these practices are also extremely beneficial for internal organisational environment such as organisational commitment especially the affective commitment. Further, these practices generate positive competitive workforce environment, where every individual seeks to boost his/her knowledge, skills, and competences as demanded by the organisation, which consecutively enhance their contribution towards high-quality customer services and reduce the shortage of required skills for a particular position. Additionally, it develops our understanding about outcomes of TM practices at individual levels. These practices help to enhance employees' motivational levels, increase their commitment, improve their work quality, enhance productivity, enlarge employees' trust towards their leaders/mentors, increase employees' morale, their perception about career success, and increase their intensity of job satisfaction.

\section{THEORETICAL CONTRIBUTIONS}

This study has contributions for the researchers, academics, scholars, practitioners, and professionals. From the theoretical perspective, our research demonstrated the importance of TM practices for organisational success. The prior literature has been reviewed to offer a basic and new framework of TM practices. In the present study, TM along with its antecedents and consequences represents a continuous cycle of strategic activities, which can be termed as 'Talent Management Life cycle' as hinted by Schiemann (2014); Newhouse et al. (2004). However, in the literature, TM Life Cycle had not been conceptualised along with antecedents and consequences. Figures 1 and 2 offers a fresh and more inclusive view of the TM life cycle. Further, call for antecedents and consequences of succession planning (Mayerhofe et al., 2004) also stands addressed in this study. 


\section{ECONOMIC CONTRIBUTIONS}

In the present environment, where organisations are competing with historically economic conditions that impact both short-term solvency and long-term value creation, TM practices, the integrated system of strategies, policies, and programmes designed to Exploring talent management practices: antecedents and consequences, identify, develop, deploy, and retain talent helps to achieve strategic objectives and meet future business needs (Silzer and Dowell, 2010).

The first and major economic implication of TM practices is that these practices help to fill the gap in talent supply and talent demand within the organisation. Whenever the organisation needs high-potential performers, TM addresses this through already identified and developed talent (employees).

Second, some of the tools and techniques used under the TM process are similar to the traditional HRM techniques such as performance evaluation, assessments, which reduce extra expenditure on arranging these techniques particularly for TM.

Further, for facing today's knowledge-based economy, TM practices are competent to provide high-quality workers with high levels of cognitive ability, skills, and competences for more complex roles. These practices also help to retain and motivate the talented employees (as also suggested by Vaiman (2010)), which will reduce the cost to be incurred on recruitment, selection, training, and development of new employees.

Lastly, at the time of economic disaster, organisations immediately resort to downsizing for reducing operating costs. Under this condition, ill effects of downsizing will be minimised due to well established TM process as there will be no need to spend extra amount on talent identification for pivotal position. Organisation can select the talented employees from succession planning programme. Additionally, internal EB will also help to identify and retain talented employees. Further, the financial and nonfinancial (at organisational level) outcomes of TM practices will yield economic benefits through increased revenues, customer satisfaction, improved quality, increase in productivity, reduced cost, reduced cycle time, and increase in return to shareholders, return on investment and market shares.

\section{MANAGERIAL CONTRIBUTIONS}

Our propositions have direct managerial implications, which can help managers to attain organisational goal more efficiently. The foremost implication is that at the time of exercising TM practices, managers should divert their mindset from traditional HRM practices to strategic HRM practices (TM) that leads to financial and non-financial outcomes.

Further, managers should focus on proper implementation of TM practices that enhance the value component of the human assets, which provides competitive edge to the organisation same as suggested by Iles et al. (2010). Further, TM is much more than the theoretical or psychological concept. Hence, there is need to shift from its discussion informally or casually to strategic implementation and alignment with managers' decision-making process (Vaiman et al., 2012).

Further, the enigma regarding what is talent in the organisation needs to be resolved. Hence, HR managers' foremost and crucial responsibility is to define the talent for their organisation through proper job specification (Farley, 2005). As a result, at the time of implementing TM practices, the different stakeholders will have clear knowledge about their talent. This exercise automatically reduces the time and energy of practitioners or experts. Further, the study suggests that top management, senior executives, and HR specialist's contributions are very essential in the initial stage of TM. The lack of talent managing mindset among top management 
may harm strategic implementation of TM practices or may result in negative outcomes at organisational as well as employee level.

Therefore, top management has to prioritise these practices along with common HRM functions. Organisational culture should encourage senior executives or HR managers to elevate talent mindset, by giving incentives, awards like Best Talent Mindset Award, Best Talent Managing Consultant Award, and so on. Besides, top management should pay attention towards managing and developing talented middle and line managers and also encourage them for participation in talent managing decision-making process as they are the ones who have the operational responsibility for managing their staff. Further, succession planning has an important role for managing other TM practices viz., talent identification, talent development, and talent retention. Accordingly, managers must focus on proper designing and execution of succession planning by forming talent pools for different types of talented employees in the organisation. Further, top management should also consult middle and lower level managers while taking strategic decisions regarding implementation and execution of succession planning in the organisation.

Moreover, for the successful implementation of TM practices, every manager should maintain separate and updated database of their talented employees, which captures the details of individual job roles, their contributions, their capabilities and skills, their specialisations, career planning and so on. Managers should review that database at the time of talent identification, succession planning, talent development, and talent retention practices. Further, management should have distinctive talent managing tools and techniques for identification, succession planning, development, and retention of TM. Further, for succession planning, management must have appropriate definition, assessments, and information about the success factors that differentiate successor's potential from other employees.

Further, managers should also endeavour other relevant and unique talent handling practices within the organisations on continuous pedestal such as talent review (to spotlight individual and organisational capability issues), talentship (well-developed decision science for human capital or talent). Further, management should appoint talent masters or experts (experts in talent managing practices), who handle only talent-related issues. They should conduct brainstorming sessions to upgrade the performance and potential appraisals process for better talent identification followed by other TM practices.

Before practising and realising these implications, managers should accept the challenge to build the TM process. Besides utilising talented employees' potentials, organisations should assess their objectives first and subsequently ensure what type of skills, knowledge, core competencies or behaviours are required for achieving these objectives.

\section{IMPLICATIONS FOR FUTURE RESEARCH}

The conceptualisation of this study suggests that due to importance of TM and the need for empirical research, there is scope for future research. This study will be of interest to practitioners, researchers and scholars in designing and developing TM practices model. The foremost limitation of our study is that it is currently at the conceptual stage of development. Hence, future research should empirically test the derived propositions in various sectors viz., banking sector, multinational companies, telecommunications sector and so on. Future TM studies should aim at developing alternate model by including other practices of TM in our conceptual framework such as talent attraction, talent engagement, and talent deployment, which might predict TM process more effectively, smoothly and be beneficial for the organisation, employees, and social market too.

Although, this study covers almost all the consequences of TM practices, there is a possibility to have more predictors that affects TM practices such as the role of mentor in talent 
identification, succession planning, talent development, and talent retention. Moreover, future research should examine the mediating role of TM practices in between the antecedents and consequences. Additionally, internal TM practices are supportive in nature for enhancing the company's attractiveness for the new applicants, who are seeking for jobs in the organisation. Hence, in future, authors can explore the impact of internal TM practices (viz., talent identification, succession planning, talent development, and talent retention) on new applicants' behaviours.

\section{CONCLUSION}

The researcher has consolidated the existing literature on TM for designing an integrated model of TM including its antecedents and consequences. The study calls future research to empirically test the derived propositions. The paper includes various theoretical, economic, managerial, and future research implications.

\section{REFERENCES}

[1] Areiqat, A.Y., Abdelhadi, T. and Al-Tarawneh, H.A. (2010) 'Talent management as a strategic practice of human resources management to improve human performance', Interdisciplinary Journal of Contemporary Research in Business, Vol. 2, No. 2, pp.329-341.

[2] Ashton, C. and Morton, L. (2005) 'Managing talent for competitive advantage: taking a systematic approach to talent management', Strategic HR Review, Vol. 4, pp.28-31.

[3] Backhaus, K. and Tikoo, S. (2004) 'Conceptualizing and researching employer branding', Career Development International, Vol. 9, No. 5, pp.501-517.

[4] Bano, S., Khan, M.A., Rehman, Q.H.U. and Humayoun, A.A. (2010) 'Schematizing talent management: a core business issue', Far East Journal of Psychology and Business, Vol. 2, No. 1, pp.4-16.

[5] Barney, J.B. (1991) 'Firm resources and sustained competitive advantage', Journal of Management, Vol. 17, No. 1, pp.99-121.

[6] Basri, E. and Box, S. (2008) The Global Competition for Talent: Mobility of the Highly Skilled, Organization for Economic Co-operation and Development (OECD), Paris.

[7] Batt, R. (2002) 'Managing customer services: human resource practices, quit rates, and sales growth', Academy of Management Journal, Vol. 45, pp.587-597.

[8] Becker, B.E., Huselid, M.A. and Beatty, R.W. (2009) The Differentiated Workforce: Transforming Talent into Strategic Impact, Harvard Business School Press, Boston, MA.

[9] Beechler, S. and Woodward, I.C. (2009) 'The global war for talent', Journal of International Management, Vol. 15, No. 3, pp.273-285.

[10] Berger, L. and Berger, D. (2010) The Talent Management Handbook: Creating a Sustainable Competitive Advantage by Selecting, Developing, and Promoting the Best People, 2nd ed., McGraw-Hill Professional, ISBN:978-007-173905-4.

[11] Bethke-Langenegger, P., Mahler, P. and Staffelbach, B. (2011) 'Effectiveness of talent management strategies', European Journal of International Management, Vol. 5, No. 5, pp.524539. 
[12] Bhatnagar, J. (2007) 'Talent management strategy of employee engagement in Indian ITES employees: key to retention', Employee Relations, Vol. 29, No. 6, pp.640-663.

[13] Blass, E., Knights, A. and Orbea, A. (2006) 'Developing future leaders: the contribution of talent management', Ashridge Business School Presented at Fifth International Annual Conference on Leadership, Cranfield, 14-15 December, pp.1-21.

[14] Boudreau, J.W. and Ramstad, P.M. (2005) 'Talentship, talent segmentation, and sustainability: a new HR decision science paradigm for a new strategy definition', Human Resource Management, Vol. 44, No. 2, pp.129-136.242 J. Jyoti and R. Rani

[15] Bryan, L., Joyce, C. and Weiss, L. (2006) 'Making a market in talent', McKinsey Quarterly, Vol. 2, No. 2, pp. 98-109.

[16] Burkus, D. and Osula, B. (2011) 'Faulty Intel in the war for talent: Replacing the assumptions of talent management with evidence-based strategies', Journal of Business Studies Quarterly, Vol. 3, No. 2, pp.1-9.

[17] Cappelli, P. (2008a) 'Talent management for the twenty-first century', Harvard Business Review, Vol. 86, No. 3, pp.74-81.

[18] Cappelli, P. (2008b) Talent on Demand: Managing Talent in an Age of Uncertainty, Harvard Business Press, Boston, Mass.

[19] Chambers, E.G., Foulton, M., Handfield-Jones, H., Hankin, S.M. and Michaels, E.G. (1998) 'The war for talent', McKinsey Quarterly, Vol. 3, pp.44-57.

[20] Cheese, P., Farley, C. and Gibbons, A. (2009) 'The new talent equation', Outlook: The Journal of High-Performance Business, pp.1-10.

[21] Chhabra, N.L. and Mishra, A. (2008) 'Talent management and employer branding: retention battle strategies', ICFAI Journal of Management Research, Vol. 7, No. 11, pp.50-61.

[22] Chugh, S. and Bhatnagar, J. (2006) 'Talent management as high performance work practice: emerging strategic HRM dimension', Management and Labour Studies, Vol. 31, No. 3, pp.228253.

[23] Clake, R. and Winkler, V. (2006) Change Agenda: Reflections on Talent Management, Chartered Institute for Personnel Development (CIPD), London.

[24] Collings, D.G. and Mellahi, K. (2009) 'Strategic talent management: a review and research agenda’, Human Resource Management Review, Vol. 19, No. 4, pp.304-313.

[25] Collings, D.G., Scullion, H. and Vaiman, V. (2011) 'European perspectives on talent management', European Journal of International Management, Vol. 5, No. 5, pp.453-462.

[26] Coltman, T., Devinney, T.M., Midgley, D.F. and Venaik, S. (2008) 'Formative versus reflective measurement models: Two applications of formative measurement', Journal of Business Research, Vol. 61, No. 12, pp.1250-1262.

[27] Conaty, B. and Charan, R. (2010) The Talent Masters: Why Smart Leaders Put People Before Numbers, Random House, New York.

[28] Connors, L., Graft, L., Joosten, T., Lowe, M. and Stone, P. (2008) 'Driving sustainable growth through talent at beneficial financial group', People and Strategy, Vol. 31, No. 3, pp.25-29. 
Research Paper on Exploring Talent Management Practices: Antecedents and Consequences

[29] Cooke, F.L., Saini, D.S. and Wang, J. (2014) 'Talent management in China and India: a comparison of management perceptions and human resource practices', Journal of World Business, Vol. 49, pp.225-235.

[30] Davies, B. and Davies, B.J. (2010) 'Talent management in academies', International Journal of Educational Management, Vol. 24, pp.418-426.

[31] Dell, D. and Hickey, J. (2002) Sustaining the Talent Quest, The Conference Board, New York.

[32] Deloitte (2010) Talent Edge 2020: Blueprints for the New Normal, http://www.deloitte.com/ assets/DcomUnitedStates/Local\%20Assets/Documents/IMOs/Talent/us_talentedge2020_1217 10.pdf

[33] Diamond, A. (2006) 'Finding success through succession planning', Security Management, Vol. 50 , No. 2, pp.36-39.

[34] DiRomualdo, T., Joyce, S. and Bression, N. (2009) Key Findings from Hackett's Performance Study on Talent Management Maturity, Hackett Group, Palo Alto.

[35] Donahue, K. (2001) 'Time to get serious about talent management', Harvard Management Update, Vol. 6, No. 7, pp.6-7.

[36] Dries, N. (2013) 'The psychology of talent management: a review and research agenda', Human Resource Management Review, available at http://dx.doi.org/10.1016/j.hrmr.2013.05.001. (Advance online publication).

[37] Edwards, M.R. and Bartlett, T.E. (1983) 'Innovations in talent identification', SAM Advanced Management Journal, Vol. 48, No. 4, pp.16-22. Exploring talent management practices: antecedents and consequences 243

[38] Elegbe, J.A. (2010) Talent Management in the Developing World, Farnham, Survey, Ashgate Publishing Group, Great Britain.

[39] Farashah, A.D., Nasehifar, V. and Karahrudi, A.S. (2011) 'Succession planning and its effects on employee career attitudes: Study of Iranian governmental organizations', African Journal of Business Management, Vol. 5, No. 9, pp.3605-3613.

[40] Farley, C. (2005) 'HR's role in talent management and driving business results', Employment Relations Today, Vol. 32, pp.55-61.

[41] Farndale, E., Scullion, H. and Sparrow, P. (2010) 'The role of the corporate HR function in talent management', Journal of World Business, Vol. 45, No. 2, pp.161-168.

[42] Fawzi, N. (2013) The Role of Recruitment, Training and Development in Achieving Employee's Effectiveness in the Banks of Kingdom of Saudi Arabia, PhD Thesis, University of Hull, UK.

[43] Festing, M., Schafer, L. and Scullion, H. (2013) 'Talent management in medium-sized German companies: an explorative study and agenda for future research', The International Journal of Human Resource Management, Vol. 24, No. 9, pp.1872-1893.

[44] Fey, C.F., Bjorkman, I. and Pavlovskaya, A. (2000) 'The effect of human resource management practice on firm performance in Russia', International Journal of Human Resource Management, Vol. 11, pp.1-18. 
[45] Figliolini, A.J., Hofmann, A. and Kanjirath, T. (2008) Growth in the Middle East and HR Capabilities, Center for Advancement of Human Resource Studies, Dubai.

[46] Frank, F.D. and Taylor, C.R. (2004) 'Talent management: trends that will shape the future', Human Resource Planning, Vol. 27, pp.33-42.

[47] Frase-Blunt, M. (2003) 'Moving past 'mini-me': building a diverse succession plan means looking beyond issues of race and gender', HR Magazine, Vol. 48, No. 11, pp.95-98.

[48] Friedman, S.D. (1986) 'Succession systems in large corporations: characteristics and correlates of performance', Human Resource Management, Vol. 25, pp.191-213.

[49] Gagne, F. (1999) 'My convictions about the nature of abilities, gifts, and talents', Journal for the Education of the Gifted, Vol. 22, No. 2, pp.109-136.

[50] Gallardo-Gallardo, E., Dries, N. and Gonzalez-Cruz, T. (2012) 'What is the meaning of 'talent' in the world of work?', Human Resource Management Review, Vol. 23, pp.290-300.

[51] Gandossy, R. and Kao, T. (2004) 'Talent wars: out of mind, out of practice', Human Resource Planning, Vol. 27, No. 4, pp.15-19.

[52] Garman, A.N. and Glawe, J. (2004) ‘Succession planning', Consulting Psychology Journal, Vol. 56, pp.119-128.

[53] Garrow, V. and Hirsh, W. (2008) 'Talent management: issues of focus and fit', Public Personnel Management, Vol. 37, No. 4, pp.389-402.

[54] Gatewood, R.D., Gowan, M.A. and Lautenschlager, G.J. (1993) 'Corporate image, recruitment image, and initial job choice decisions', Academy of Management Journal, Vol. 36, pp.414427.

[55] Gberevbie, D.E. (2010) 'Organizational retention strategies and employee performance of Zenith Bank in Nigeria', African Journal of Economic and Management Studies, Vol. 1, No. 1, pp.61-74.

[56] Gehrels, S.A. and Looij, J.D. (2011) 'Employer branding a new approach for the hospitality industry', International Journal of Public Sector Management, Vol. 12, pp.1-13.

[57] Glen, C. (2006) 'Key skills retention and motivation: the war for talent still rages and retention is the high ground', Industrial and Commercial Training, Vol. 38, No. 1, pp.37-45.

[58] Golden, J. (2005) 'Talent management, succession planning, leadership development. What's needed?', Community and Junior Collect Libraries, Vol. 13, No. 4, pp.3-6.

[59] Greer, C.R. and Virick, M. (2008) 'Diverse succession planning: lessons from the industry leaders', Human Resource Management, Vol. 47, No. 2, pp.351-367.

[60] Grobler, P.A. and Diedericks, H. (2009) 'Talent management: an empirical study of selected South African hotel groups', Southern African Business Review, Vol. 13, No. 3, pp.1-27. 244 J. Jyoti and R. Rani

[61] Groves, K.S. (2011) 'Talent management best practices: How exemplary health care organizations create value in a down economy', Health Care Management Review, Vol. 36, No. 3, pp.227-240. 
[62] Guthridge, M., Komm, A.B. and Lawson, E. (2008) 'Making talent a strategic priority', McKinsey Quarterly, Vol. 1, pp.48-59.

[63] Handfield-Jones, H., Michaels, E. and Axelrod, B. (2001) 'Talent management: a critical part of every leader's job', Ivey Business Journal, Vol. 66, No. 2, pp.53-58.

[64] Hartmann, E., Feisel, E. and Schober, H. (2010) 'Talent management of Western MNCs in Chain: balancing global integration and local responsiveness', Journal of World Business, Vol. 45, No. 2, pp.169-178.

[65] Heinen, J.S. and O’Neill, C. (2004) 'Managing talent to maximize performance', Employment Relations Today, Vol. 31, No. 2, pp.67-82.

[66] Heller, K.A., Mönks, F.J. and Passow, A.H. (Eds.) (2000) International Handbook of Research and Development of Giftedness and Talent, Pergamon, Oxford.

[67] Hilal, M. (2012) Talent Management, Improve performance and development publication and distribution, Cairo.

[68] Hills, A. (2009) 'Succession planning or smart talent management?', Industrial and Commercial Training, Vol. 41, No. 1, pp.3-8.

[69] Horvathova, P. and Durdova, I. (2010) 'The level of talent management usage at human resources management in organizations of the Moravian-Silesian region', Business and Economic Horizons, Vol. 3, No. 3, pp.58-67.

[70] Hughes, J.C. and Rog, E. (2008) 'Talent management: a strategy for improving employee recruitment, retention and engagement within hospitality organizations', International Journal of Contemporary Hospitality Management, Vol. 20, pp.743-757.

[71] Huselid, M., Beatty, R. and Becker, B. (2005) “'A players' or 'A positions'? The strategic logic of workforce management', Harvard Business Review, Vol. 83, pp.110-117.

[72] Huselid, M.A. and Becker, B.E. (1998) High Performance Work Systems, Intellectual Capital, and The Creation of Shareholder Wealth, Rutgers University, New Jersey.

[73] Iles, P. (2008) 'Talent balancing: Staffing your company for long-term success', Human Resource Development International, Vol. 11, No. 2, pp.215-218.

[74] Iles, P. (2013) 'Commentary on 'The meaning of 'talent' in the world of work', Human Resource Management Review, http://dx.doi.org/10.1016/j.hrmr.2013.08.002 Performance in the Public Sector, University of Pittsburgh, USA.

[75] Iles, P., Chuai, X. and Preece, D. (2010) 'Talent management and HRM in multinational companies in Beijing: Definitions, differences and drivers', Journal of World Business, Vol. 45, No. 2, pp.179-189.

[76] Iqbal, S., Qureshi, T.M., Khan, A. and Hijazi, S.Z. (2013) 'Talent management is not an old wine in a new bottle', African Journal of Business Management, Vol. 7, No. 35, pp.3609-3619.

[77] Jamrog, J. (2004) 'The perfect storm: the future of retention and engagement', Human Resource Planning, Vol. 27, No. 3, pp.26-33. 
[78] Janardhanam, K., Nirmala, M. and Pandey, P. (2011) 'Talent management practices in IT sector', International Journal of Research in Commerce, IT and Management, Vol. 1, No. 2, pp.36-40.

[79] Joyce, W.F. and Slocum, J.W. (2012) 'Top management talent, strategic capabilities, and firm performance', Organizational Dynamics, Vol. 41, pp.183-193.

[80] Julia, C.H. and Rog, E. (2008) 'Talent management: a strategy for improving employee recruitment, retention and engagement within hospitality organizations', International Journal of Contemporary Hospitality Management, Vol. 20, No. 7, pp.743-757.

[81] Kaplan, R.S. and Norton, D.P. (1996) Translating Strategy into Action the Balanced Scorecard, Harvard Business School Press, Boston, MA. Exploring talent management practices: antecedents and consequences 245

[82] Kaur, R. (2013) 'Empirical study of talent management program and its impact on the employee's retainment and performance in Indian supermarket big bazaar', Human Resource Management Research, Vol. 3, No. 3, pp.61-70.

[83] Keegan, A. and Boselie, P. (2006) 'The Lack of impact of dissensus inspired analysis on developments in the field of human resource management', Journal of Management Studies, Vol. 43, pp.1491-1511.

[84] Kelleher, B. (2011) 'Employee engagement and retention', American Management Association International, Vol. 10, No. 1, pp.36-39.

[85] Kontoghiorghes, C. and Frangou, K. (2009) 'The association between talent retention, antecedent factors, and consequent organizational performance', SAM Advanced Management Journal, Vol. 74, No. 1, pp.29-58.

[86] Lakshmi, M.S., Srinivas, K. and Krishna, K.V.R. (2010) 'Employee engagement for talent retention with reference to the academicians', Review of Business Research, Vol. 10, No. 3, pp.137-142.

[87] Lehmann, S. (2009) 'Motivating talents in Thai and Malaysian service firms', Human Resource Development International, Vol. 12, No. 2, pp.155-169.

[88] Lewis, R.E. and Heckman, R.J. (2006) ‘Talent management: a critical review', Human Resource Management Review, Vol. 16, No. 2, pp.139-154.

[89] Lockwood, D. and Ansari, A. (1999) 'Recruiting and retaining scarce information technology talent: a focus group study', Industrial Management and Data Systems, Vol. 99, No. 6, pp.251256.

[90] Lockwood, N.R. (2006) 'Talent management: driver for organizational success', The Society for Human Resource Management Research Quarterly, pp.2-11.

[91] Lockwood, N.R. (2007) 'Leveraging employee engagement for competitive advantage: HR's strategic role', The Society for Human Resource Management Research Quarterly, pp.2-11.

[92] Lockwood, N.R. (2010) 'Employer brand in India: a strategic HR tool', The Society for Human Resource Management Research Quarterly, pp.2-13.

[93] Lombardo, M.M. and Eichinger, R.W. (2000) 'High potentials as high learners', Human Resource Management, Vol. 9, No. 4, pp.321-329. 
[94] Makela, K., Bjorkman, I. and Ehrnooth, M. (2010) 'How do MNCs establish their talent pools? Influences on individuals' likelihood of being labeled as talent', Journal of World Business, Vol. 45, No. 2, pp.134-142.

[95] Mandhanya, Y. and Shah, M. (2010) 'Employer branding: a tool for talent management', Global Management Review, Vol. 4, No. 2, pp.43-48.

[96] Martin, J. and Schmidt, C. (2010) 'How to keep your top talent', Harvard Business Review, Vol. 88, pp.54-61.

[97] Mayerhofer, H., Hartmann, L. C., Michelitsch-Riedl, G. and Kollinger, I. (2004) 'Flexpatriate assignments: a neglected issue in global staffing', The International Journal of Human Resource Management, Vol. 15, No. 8, pp.1371-1389.

[98] McCauley, C. and Wakefield, M. (2006) 'Talent management in the 21st century: Help your company find, develop, and keep its strongest workers', Journal for Quality and Participation, Vol. 29, No. 4, pp.4-7.

[99] McDonnell, A. (2011) 'Still fighting the "War for Talent"? Bridging the science versus practice gap', Journal Business Psychology, Vol. 26, pp.169-173.

[100] Meyers, M.C. and Woerkom, M.V. (2014) 'The influence of underlying philosophies on talent management: theory, implications for practice, and research agenda', Journal of World Business, Vol. 49, pp.192-203.

[101] Michaels, E., Handfield-Jones, H. and Axelrod, B. (2001) The War for Talent, Harvard Business School, Boston.

[102] Morgan, H.J. (2008) 'Keeping your talent identifying and retaining your star keys', Strategic Direction, Vol. 24, No. 9, pp.6-8. 246

[103] J. Jyoti and R. Rani Moroko, L. and Uncles, M.D. (2008) 'Characteristics of successful employer brands', Brand Management, Vol. 16, No. 3, pp.160-175.

[104] Morton, L. (2005) Talent Management Value Imperatives: Strategies for Successful Execution, Research Report R-1360-05-RR, Conference Board.

[105] Mosley, R.W. (2007) 'Customer experience, organizational culture and the employer brand', Brand Management, Vol. 15, No. 2, pp.123-134.

[106] Mucha, R.T. (2004) 'The art and science of talent management', Organization Development Journal, Vol. 22, No. 4, pp.96-100.

[107] Nankervis, A.R. (2013) 'Building for the future? Government and industry responses to the challenges of talent management in China following the GFC', Asia Pacific Business Review, Vol. 19, No. 2, pp.186-199.

[108] Newhouse, N.K., Lewis, B.O. and Jones, J.W. (2004) 'Strategic talent management: assessments as a foundation', Poster presented at the Annual Conference of the Society for Personality Assessment, Miami, FL, 11 March, pp.1-11.

[109] Paauwe, J. (2007) HRM and Performance: In Search of Balance, Tilburg University, Netherlands. 
[110] Perrin, T. (2005) Winning Strategies for a Global Workforce: Attracting, Retaining, and Engaging Employees for Competitive Advantage, Towers Perrin Global Workforce Study, Executive Report TP449-05, Towers Perrin, Stamfor., CT,

[111] Piansoongnern, O. and Anurit, P. (2010) 'Talent management: quantitative and qualitative studies of HR practitioners in Thailand', The International Journal of Organizational Innovation, Vol. 3, No. 1, pp.280-302.

[112] Piansoongnern, O., Anurit, P. and Kuiyawattananonta, S. (2011) 'Talent management in Thai cement companies: a study of strategies and factors influencing employee engagement', African Journal of Business Management, Vol. 5, No. 5, pp.1578-1583.

[113] Pollitt, D. (2009) 'Success through succession at Hudson's bay company', Human Resources Management Digest, Vol. 17, No. 5, pp.6-8, doi 10.1108/09670730910974260.

[114] Powell, J., Durose, J., Duberly, J., Exworthy, M., Fewtrell, C., MacFarlane, F. and Moss, P. (2012) Talent Management in the NHS Managerial Workforce, Final Report, National Institute for Health Research, pp.1-216.

[115] Powell, M. and Lubitsh, G. (2007) 'Courage in the face of extraordinary talent: Why talent management has become a leadership issue', Strategic HR Review, Vol. 6, No. 2, pp.24-27.

[116] Priyadarshi, P. (2011) 'Employer brand image as predictor of employee satisfaction, affective commitment and turnover', The Indian Journal of Industrial Relations, Vol. 46, No. 3, pp.510 522 .

[117] Puvitayaphan, A. (2008) 'Talent management practices in selected companies listed on the stock exchange of Thailand', Educational Journal of Thailand, Vol. 2, No. 1, pp.1-9.

[118] Ram, P. and Prabhakar, G.V. (2011) 'The role of employee engagement in work-related outcomes', Interdisciplinary Journal of Research in Business, Vol. 1, No. 3, pp.47-61.

[119] Ready, A.D. and Conger, A.J. (2007) 'Talent factory', in Ready, D.A. and Conger, J.A. (Eds.): Harvard Business Review, pp.69-77.

[120] Ringo, T., Schweyer, A., DeMarco, M., Jones, R. and Lesser, E. (2008) Integrated Talent Management: Part 3 - Turning Talent Management into a Competitive Advantage, IBM Corporation, Somers, NY.

[121] Ritson, M. (2002) 'Marketing and HE collaborate to harness employer brand power', Marketing, p.24.

[122] Rothwell, W.J. (2010) Effective Succession Planning, Ensuring Leadership Continuity and Building Talent from Within, 4th ed., American Management Association, New York.

[123] Ruwaili, N.F., Al Bright, D. and Alhameed, A. (2013) 'To what extent talent management in Saudi Arabian banks', International Journal of Advances in Management Science, Vol. 2, No. 1, pp.9-15.

[124] Exploring talent management practices: antecedents and consequences 247

[125] Sandler, S.F. (2006) 'Critical issues in HR drive 2006 priorities: \#1 is talent management', HR Focus, Vol. 83, No. 1, pp.13-15. 
Research Paper on Exploring Talent Management Practices: Antecedents and Consequences

[126] Saxena, P. (2013) 'Talent management: a strategic perspective', Anveshanam - A National Journal of Management, Vol. 1, No. 1, pp.49-55.

[127] Schaufeli, W.B. and Bakker, A.B. (2004) 'Job demands, job resources, and their relationship with burnout and engagement: a multi-sample study', Journal of Organizational Behavior, Vol. 25, No. 3, pp.293-315.

[128] Schiemann, W.A. (2014) 'From talent management to talent optimization', Journal of World Business, Vol. 49, pp.281-288.

[129] Schuler, R.S., Jackson, S.E. and Tarique, I. (2011) 'Global talent management and global talent challenges: strategic opportunities for IHRM’, Journal of World Business, Vol. 46, pp.506-516.

[130] Schweyer, A. (2004) Talent Management Systems: Best Practices in Technology Solutions for Recruitment, Retention and Workforce Planning, Wiley, Hoboken, NJ.

[131] Sebald, H., Enneking, A. and Wöltje, O. (2005) Talent Management: Zwischen Anspruch und Wirklichkeit, Towers Perrin, Frankfurt am Main.

[132] Seifert, M. and Hadida, A.L. (2006) 'Facilitating talent selection decisions in the music industry',Management Decision, Vol. 44, No. 6, pp.790-808.

[133] Silzer, R. and Church, A.H. (2010) 'Identifying and assessing high-potential talent: current organizational practices', in Silzer, R. and Dowell, B.E. (Eds.): Strategy-Driven Talent Management: A Leadership Imperative, Jossey-Bass, San Francisco, pp.213-279.

[134] Silzer, R. and Dowell, B.E. (2010) Strategy-Driven Talent Management: A Leadership Imperative, Jossey-Bass, San Francisco.

[135] Snell, A. (2007) 'Strategic talent management, human resource management: the relationship of mentoring and network resources with career success in the Chinese organizational environment', International Journal of Human Resource Management, Vol. 17, No. 9, pp.15311546.

[136] Stahl, G.K., Bjorkman, I., Farndale, E., Morris, S.S., Paauwe, J., Stiles, P., Trevor, J. and Wright, P. (2012) 'Six principles of effective global talent management', MIT Sloan Management Review, Vol. 53, pp.25-32.

[137] Stairs, M., Galpin, M., Page, N. and Linley, A. (2006) 'Retention on a knife edge: the role of employee engagement in talent management', Selection and Development Review, Vol. 22, No. 5, pp.19-23.

[138] Steinweg, S. (2009) Systematisches Talent Management: Kompetenzen Strategisch Einsetzen, Schäffer-Poeschel, Stuttgart.

[139] Stewart, J. (2008) 'Developing skills through talent management', SSDA Catalyst, No. 6, pp.114.

[140] Stuart-Kotze, R. and Dunn, C. (2008) Who are you Best People? How to Find, Measure and Manage your Top Talent, Prentice Hall, Britain.

[141] Sumardi, W.A. and Othman, R. (2009) 'The three faces of talent management in Malaysia', International Journal of Business Research, Vol. 10, No. 1, pp.181-185. 
[142] Sutherland, M.M., Torricelli, D.G. and Karg, R.F. (2002) 'Employer of choice branding for knowledge workers', South African Journal of Business Management, Vol. 33, No. 4, pp.1320 .

[143] Swailes, S. (2013) 'The ethics of talent management', Business Ethics: A European Review, Vol. 22, pp.32-46.

[144] Tansley, C. (2009) 'Concept borrowing to facilitate a multi-disciplinary approach to the theoretical development of talent management-the case of employer branding', Paper presented at the European Academy of Management Conference, Book of Abstracts, p.48.

[145] Tansley, C. (2011) 'What do we mean by the term 'talent' in talent management?', Industrial and Commercial Training, Vol. 43, No. 5, pp.236-247. 248 J. Jyoti and R. Rani

[146] Tansley, C. and Sempik, A. (2008) Talent Management: Design, Implementation and Evaluation, CIPD, London.

[147] Tansley, C. and Tietze, S. (2013) 'Rites of passage through talent management progression stages: An identity work perspective', The International Journal of Human Resource Management, Vol. 24, No. 9, pp.1799-1815.

[148] Tansley, C., Foster, C., Harris, L., Stewart, J., Sempik, A., Turner, P. and Williams, H. (2007) Talent: Strategy, Management and Measurement, CIPD, London.

[149] Tarique, I. and Schuler, R.S. (2010) 'Global talent management: Literature review, integrative framework, and suggestions for further research', Journal of World Business, Vol. 45, pp.122133.

[150] Thunnissen, M., Boselie, P. and Fruytie, B. (2013) 'A review of talent management: Infancy or adolescence?', The International Journal of Human Resource Management, Vol. 24, No. 9, pp.1744-1761.

[151] Tymon, W., Stumpf, S.A. and Doh, J.P. (2010) 'Exploring talent management in India: the neglected role of intrinsic rewards', Journal of World Business, Vol. 55, pp.109-121.

[152] Vaiman, V. (2010) 'Managing talent of non-traditional knowledge workers: opportunities, challenges, and trends in talent management of knowledge employees: embracing nontraditional workforce', in Vaiman, V. (Ed.): Palgrave Macmillan, London, pp.1-22.

[153] Vaiman, V. and Collings, D.G. (2013) 'Talent management: advancing the field', The International Journal of Human Resource Management, Vol. 24, No. 9, pp.1737-1743.

[154] Vaiman, V., Scullion, H. and Collings, D.G. (2012) 'Talent management decision making', Management Decision, Vol. 50, No. 5, pp.925-941.

[155] Valverde, M., Scullion, H. and Ryan, G. (2013) 'Talent management in Spanish medium-sized organizations', The International Journal of Human Resource Management, Vol. 24, No. 9, pp.1832-1852.

[156] van Dijk, H.G. (2008) 'The talent management approach to human resource management: attracting and retaining the right people', Journal of Public Administration, Vol. 43, No. 1, pp.385-395. 
Research Paper on Exploring Talent Management Practices: Antecedents and Consequences

[157] Wahjosoedibjo, A.S. (2009) 'The role of senior leadership in human capital and talent management', Presented at the 36th ARTDO International Conference Penang, Malaysia, 4-6 October, Available at www.penconsuting.com

[158] White, H.L. (2009) 'Talent development and management: optimizing human performance in the public sector', Presented at the International Conference on Administrative Development: Towards Excellence in Public Sector Performance, King Faisal Hall for Conferences, Riyadh, Kingdom of Saudi Arabia, 1-4 November, Available at Xa.yimg.com

[159] Wright, P.M., Dunford, B.B. and Snell, S.A. (2001) 'Human resources and the resource based view of the firm', Journal of Management, Vol. 27, pp.701-721.

[160] Yapp, M. (2009) 'Measuring the ROI of talent management', Strategic HR Review, Vol. 8, No. 4, pp.5-10.

[161] Yarnall, J. (2011) 'Maximizing the effectiveness of talent pools: a review of case study literature', Leadership and Organization Development Journal, Vol. 32, No. 5, pp.510-526.

[162] Yue Ngo, H., Minglau, C. and Foley, S. (2008) Strategic Human Resource Management, firm Performance, and Employee Relations Climate in China, Wiley Inter Science, Published Online.

[163] Zhang, S. and Bright, D. (2012) 'Talent definition and talent management recognition in Chinese private-owned enterprises', Journal of Chinese Entrepreneurship, Vol. 4, No. 2, pp.2645 . 